\title{
Faunal composition and paleoenvironment of the Arundel Clay (Potomac Formation; Early Cretaceous), Maryland, USA
}

\author{
Joseph A. Frederickson, Thomas R. Lipka, and Richard L. Cifelli
}

\begin{abstract}
The Arundel Clay facies of the Potomac Group represents one of the few Lower Cretaceous vertebrate-bearing deposits in the Atlantic coastal plain. Vertebrate fossils from this unit have been known for more than 150 years, but thus far formal descriptions have mainly concentrated on its dinosaurs and mammals. Herein, we eport on a moderately diverse faunal assemblage (USNM 41614) from Dinosaur Park in Prince Georges County, Maryland. This assemblage is represented by 306 disarticulated macro- and microfossils that largely consist of teeth and scales (89\%). This vertebrate fauna includes two species of hybodont sharks, multiple semionotid fishes, one species of lungfish, three species of turtle, three families of neosuchian crocodilians, six species of dinosaurs, and two species of mammals. Combined with other historical collections from this unit, these new additions to the fauna show that the Arundel was a far more robust and diverse ecosystem than previously envisaged, broadly similar in composition to contemporaneous units of western North America. The Arundel assemblage differs, however, from those in many other Lower Cretaceous sites in that it is dominated numerically by Hybodus and goniopholidid crocodylomorphs, which together comprise $58 \%$ of catalogued specimens. Similarly, this sample entirely lacks lissamphibians and lepidosaurs. Traditionally, the Arundel has been interpreted as being of fluvial origin, deposited in a freshwater system of stranded channels or oxbows. Based on faunal composition, together with published geological and sedimentological evidence, we propose that at least some of the Arundel facies was deposited in close proximity to the Atlantic Ocean.
\end{abstract}

Joseph A. Frederickson. Sam Noble Museum, 2401 Chautauqua Avenue, Norman, Oklahoma, 73072, USA and Department of Biology, University of Oklahoma, Norman, Oklahoma, 73019, USA. joe.frederickson@swosu.edu Thomas R. Lipka. Sam Noble Museum, 2401 Chautauqua Avenue, Norman, Oklahoma, 73072, USA thomas.r.lipka-1@ou.edu

Richard L. Cifelli. Sam Noble Museum, 2401 Chautauqua Avenue, Norman, Oklahoma, 73072, USA and Department of Biology, University of Oklahoma, Norman, Oklahoma, 73019, USA. rlc@ou.edu

Keywords: Arundel Clay; Potomac Formation; Early Cretaceous; paleoecology; dinosaurs

Submission: 3 January 2018 Acceptance: 3 August 32018

Frederickson, Joseph A., Lipka, Thomas R., and Cifelli, Richard L. 2018. Faunal composition and paleoenvironment of the Arundel Clay (Potomac Formation; Early Cretaceous), Maryland, USA. Palaeontologia Electronica 21.2.31A 1-24. https://doi.org/10.26879/847 palaeo-electronica.org/content/2018/2290-arundel-fauna-of-maryland-usa

Copyright: August 2018 Society of Vertebrate Paleontology.

This is an open access article distributed under the terms of the Creative Commons Attribution License, which permits unrestricted use, distribution, and reproduction in any medium, provided the original author and source are credited.

creativecommons.org/licenses/by/4.0/ 


\section{INTRODUCTION}

Fossils from the Lower to basal Upper Cretaceous Potomac Formation have been known to science for over 150 years (Johnston, 1859; Leidy, 1865), making it one of the longest-studied Cretaceous formations in America. Although of primary interest to colonial and early American industrialists for its abundant iron ore deposits, the Arundel Clay facies of the Potomac has long been recognized as an important fossil-bearing unit that was similar in composition to the better-known dinosaur-bearing formations of the American West (e.g., Marsh, 1888). To this day, the Arundel continues to be the only substantial source for Early Cretaceous terrestrial vertebrates from the eastern seaboard of North America. Because of its significance, multiple studies have been undertaken to describe fossils from the Arundel Clay. However, the literature is strongly biased toward the dinosaurs recovered from the unit (e.g., Lull, 1911; Gilmore, 1921; Kranz, 1989; Weishampel and Young, 1998; Lipka, 1998; Brownstein, 2017). Only a few papers describe other vertebrates in any level of detail, with Kranz (1998b), Lipka et al. (2006), and Frederickson et al. (2016) being three recent exceptions. Here we attempt to rectify this, at least in part, by describing a diverse and ecologically informative assemblage from the Arundel Clay facies.

\section{GEOLOGIC SETTING}

The Arundel Clay represents the middle unit of the Early Cretaceous terrigenous system deposited on the coastal plain of the mid-Atlantic region (Figure 1). The unit was initially regarded as a distinct but localized formation lying above the Patuxent Formation and below the Patapsco Formation. These units, together with the Raritan Formation (now Elk Neck Beds), at the top of the sequence, constitutes the Potomac Group (Clark and Bibbins, 1897). Some recent investigators have retained this usage (e.g., Hochuli et al. 2006), but in most of the contemporary literature (e.g., Glaser, 1969; Doyle and Robbins, 1977; Lipka et al., 2006; Jud and Hickey, 2013), the Arundel Clay is regarded as an informal, unspecified unit or (as herein, following Kranz, 1998a) a facies within the Potomac Formation (reduced in rank from group). While surface exposure of the Arundel Clay facies is limited to Washington, D.C. and Maryland, most of the other Potomac units extend from southern Virginia to southern New Jersey. The Potomac is well known for its contained floral sequence (Brenner, 1963; Doyle and Robbins, 1977; Hochuli et al., 2006; Doyle, 2012), especially spores and pollen, which indicate a late Aptian or (more probably) early Albian age for the Arundel Clay facies.

The Potomac Formation was deposited within a large, meandering fluvial system draining from the Appalachian highlands to the west. Although

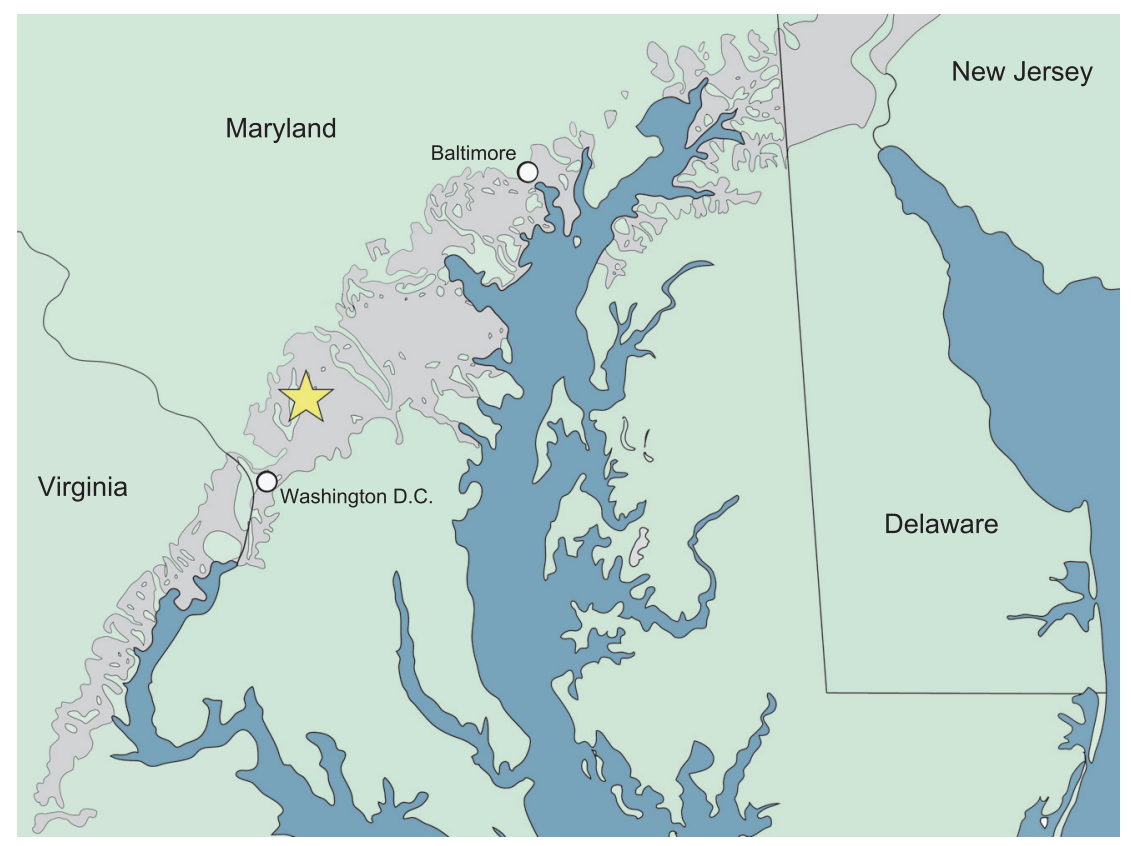

FIGURE 1. Map of Potomac Formation outcrop belt in Maryland and surrounding states with the approximate location Dinosaur Park indicated by yellow star (map modified from Jud, 2015). 
three divisions of the Potomac are formally recognized (from bottom to top, the Patuxent, Arundel, and Patapsco), the Arundel Clay is the only one that contains an appreciable vertebrate osteological fossil record. Lithologically, the Arundel Clay facies consists mainly of bluish-gray lignitic claystones with abundant ferruginous concretions (Clark and Bibbins, 1897; Kranz, 1996). The Arundel Clay facies crops out as a series of lenticular to elongate, localized deposits at or near the upper surface of the Patuxent Formation, reaching a maximum thickness of just under $40 \mathrm{~m}$ (Clark and Bibbins, 1897). These deposits have historically been interpreted as abandoned channels or oxbows in a slow-moving fluvial system (Kranz, 1998a; Lipka et al., 2006; see below for an alternative interpretation).

The sample described here was collected by TRL from USNM locality 41614 (also known as the Muirkirk site) in Prince Georges County, Maryland. The site, which lies in an area that was formerly mined for its clay (used in production of bricks) and iron ore, is now known as Dinosaur Park and is managed by the Prince Georges County Department of Parks and Recreation. (In 1973, RLC was employed as a laborer for Maryland Clay Products, which then operated the brick plant at Muirkirk, unaware and unconcerned with fossils contained by the sediments.) USNM locality 41614 has yielded a diverse vertebrate fauna (e.g., Lipka, 1998; Kranz, 1998a). To date, a lungfish (Frederickson et al., 2016), a turtle (Lipka et al., 2006), two mammals (Cifelli et al., 1999; Rose et al., 2001; Cifelli et al., 2013), and multiple dinosaurs (Gilmore, 1921; Kranz, 1998a; Brownstein, 2017) have been formally described.

\section{Institutional Abbreviations}

$\mathrm{OMNH}$ - Sam Noble Oklahoma Museum of Natural History, Norman, Oklahoma; USNM — Smithsonian United States Museum of Natural History, Washington, D.C.

\section{MATERIALS AND METHODS}

Most fossils were picked from the surface; where surface material appeared to be more concentrated, the surface was stripped and screenwashed using conventional methods (e.g., Cifelli et al., 1996). The assemblage from the Muirkirk site was compared with assemblages recovered from other relevant North American Early Cretaceous units using the primary literature (Goldberg, 2000 and Oreska et al., 2013) and abundances from collections housed at OMNH. We include taxa in our faunal list that were described from the Muirkirk site by previous authors, but specimen numbers are given only for specimens first described in this paper.

For taxa erected by Agassiz in his monumental Recherches sur les Poissons fossiles (183344 ), we cite relevant individual sections (livraisons) and their corresponding publication dates as given by Woodward and Sherborn (1890: xxv-xxix).

\section{SYSTEMATIC PALEONTOLOGY}

Class CHONDRICHTHYES Huxley, 1880

Subclass ELASMOBRANCHII Bonaparte, 1838

Superfamily HYBODONTOIDEA Agassiz, 1843

Family HYBODONTIDAE Agassiz, 1843

Genus EGERTONODUS Maisey, 1987

Egertonodus basanus Egerton, 1845

Figure 2.1-2.3, 2.7

Material. Sixteen complete and partial teeth (USNM 609321-609336) and a single cephalic spine (USNM 521182).

Description and remarks. These teeth bear a main cusp that is sigmoidal in shape, with lingual recurvature when viewed mesially or distally (Figure 2.3). The most complete specimens possess three to four pairs of lateral cusps that flank the main cusp. Robust enamel folds extend from the base of the crown to roughly halfway up (apically) the central cusp; the labial face may be smooth in some specimens. The largest of these teeth are 5 $\mathrm{mm}$ tall and $10 \mathrm{~mm}$ wide. One cephalic spine (enameled crown) is here referred to $E$. basanus (Figure 2.7), based on a favorable comparison with a specimen illustrated by Maisey (1983, figure 24).

Genus HYBODUS Agassiz, 1837

Hybodus ensis Woodward, 1916

Figure 2.4-2.6

Material. Fifteen complete or partial teeth (USNM 609337-609351).

Description and remarks. These teeth are generally larger than those referred to $E$. basanus and possess a more robust, broad-based central cusp (Figure 2.4 and 2.5). The central cusp is high with little to no lingual curvature (Figure 2.6). There are two pairs of lateral cusps present in some of the most complete specimens, but none are complete. The innermost lateral cusps are moderately tall and more distant from the central cusp than in E. basanus. Striae are small and only cover $25-50 \%$ of the central cusp, which may have fine denticles (serrations) near its base (Underwood and Reese, 2002). Maisey (1983) suggested that $H$. ensis and $E$. basanus are teeth that could have come from the 


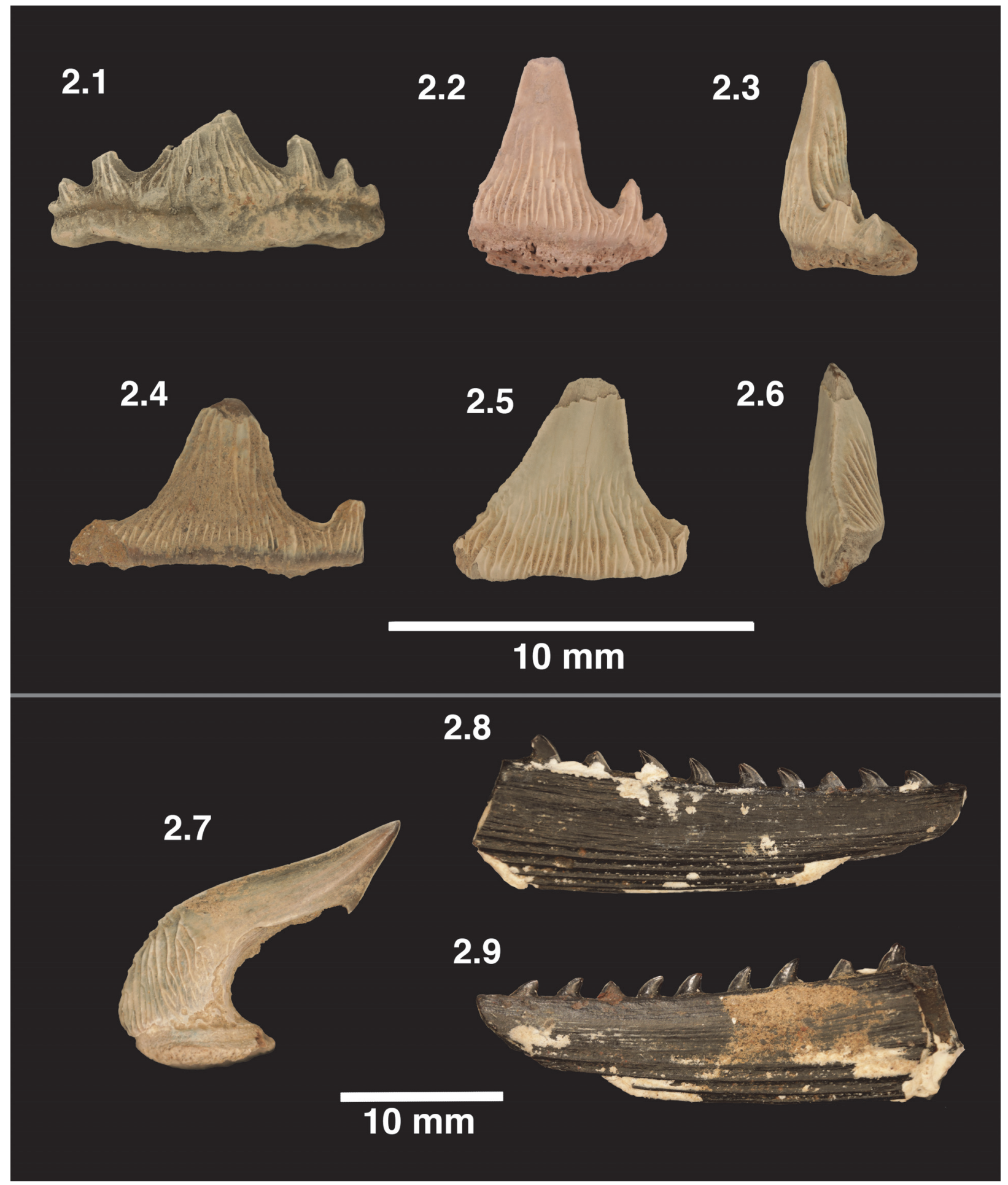

FIGURE 2. Hybodont sharks from the Arundel Clay. 2.1 USNM 609336, 2.2 and 2.3 USNM 609325, and 2.7 USNM 521182 teeth and cephalic spine from Egertonodus basanus. 2.4 USNM 609350, 2.5 and 2.6 USNM 609349, teeth from Hybodus ensis. 2.8 and 2.9 USNM 521181 dorsal spines from Hybodontoidea indet. 
same species of shark, representing different areas of the mouth. This hypothesis has not been rigorously tested, but was rejected by Underwood and Reese (2002) based on the morphological differences in the teeth and the fact that, at several localities in the Purbeck Group, E. basanus teeth are common but $H$. ensis teeth are not present.

\section{Gen. et sp. indet. \\ Figure 2.8-2.9}

Material. Isolated teeth (USNM 521185-521189, 609277-609320), three partial dorsal spines (USNM 521179-521181), and two cephalic spine bases (USNM 521183-521184).

Description and remarks. Three partial dorsal spines and two cephalic spine bases are here referred to as Hybodontoidea indeterminate; also included are several teeth that are too poorly preserved for identification. According to Underwood and Reese (2002) dorsal and cephalic spines are not yet sufficiently matched to determine their species-level designations. The dorsal spines have both double and single rows of denticles (Figure 2.8 and 2.9); this is a feature known to change dorsally moving up the spine (Thurmond, 1971; Bonde, 2004; Oreska et al., 2013). Cephalic spines in this sample show at least two different morphologies. The best-preserved specimen (Figure 2.82.9) appears similar to the cephalic horns and dorsal spines of Lonchidion in Patterson (1966); however, no Lonchidion teeth have been recovered in the Arundel sample. Given the poor knowledge concerning association of hybodontid spines to species known by teeth, it is reasonable to suspect that these elements could belong to either (or both) of the previously described species.

Class ACTINOPTERYGII Klein, 1885 Infraclass HOLOSTEI Müller, 1846 (sensu Grande, 2010)

Order SEMIONOTIFORMES Arambourg and Bertin, 1958

Family SEMIONOTIDAE Woodward, 1890 Genus LEPIDOTES Agassiz, 1832 cf. Lepidotes sp.

Figure 3.1

Material. Twelve complete and partial teeth (USNM 521155-521166), a single fragmentary jaw (USNM 521167; Figure 3.1).

Description and remarks. Two types of hemispherical semionotid teeth are present in the Arundel Clay. The first type is wide, short, and highly rounded. Each tooth of this type possesses an enamel cap on the occlusal surface, with a slight convexity near the center. The second type is simi- lar to the first, in that they are bulbous with small, apical enamel caps. However, these teeth tend to be taller and thinner than the previously described teeth (Figure 3.1). Bilelo (1969) and Estes and Sanchez (1982) recognize both tooth morphologies in Lepidotes and indicate that the shorter teeth come from the palatine and the taller conical teeth are of marginal or pharyngeal origin. A similar sample of rounded and pointed teeth from the mid-Cretaceous Cedar Mountain Formation were analyzed isotopically by Suarez et al. (2012), who showed that they had very different oxygen isotope values. This implies that these teeth represent two distinct species. Until more complete body fossils are found, it will remain difficult to determine whether these teeth represent different tooth positions within a single species or homologous teeth of different species.

Order AMIIFORMES Hay, 1929

Family AMIIDAE Bonaparte, 1841

Subfamily cf. VIDALAMIINAE Grande and Bemis, 1998

Gen. et sp. indet.

Figure 3.2

Material. Four complete and partial teeth, USNM 521168-521170.

Description and remarks. These teeth are similar in size and shape to those referred to Melvius by Brinkman et al. (2013) and Fiorillo (1999). We identify them as Vidalamiinae based on their welldeveloped carinae and arrow-shaped crowns. These teeth possess a complicated network of stylolite-like striations below the crown. Since these striations do not affect the texture of the teeth, we do not consider them to be of phylogenetic significance. Similar teeth, reported from the Cloverly Formation (Oreska et al. 2013), likely represent the same or a closely related species.

\section{cf. AMIIFORMES indet. \\ Figure 3.3-3.4}

Material. Two incomplete vertebrae, USNM 497786 and 497787.

Description and remarks. These centra have an oval outline in craniocaudal view, and bear attached parapophyseal processes. Among previously-described fossils, these vertebrae are most similar to those described by Brinkman et al. (2013, figure 10.7 D). USNM 497786 and 497787 are reminiscent of amiid fish vertebrae, but their poor preservation hinders confident identification.

HOLOSTEl indet.

Figure 3.5-3.10 


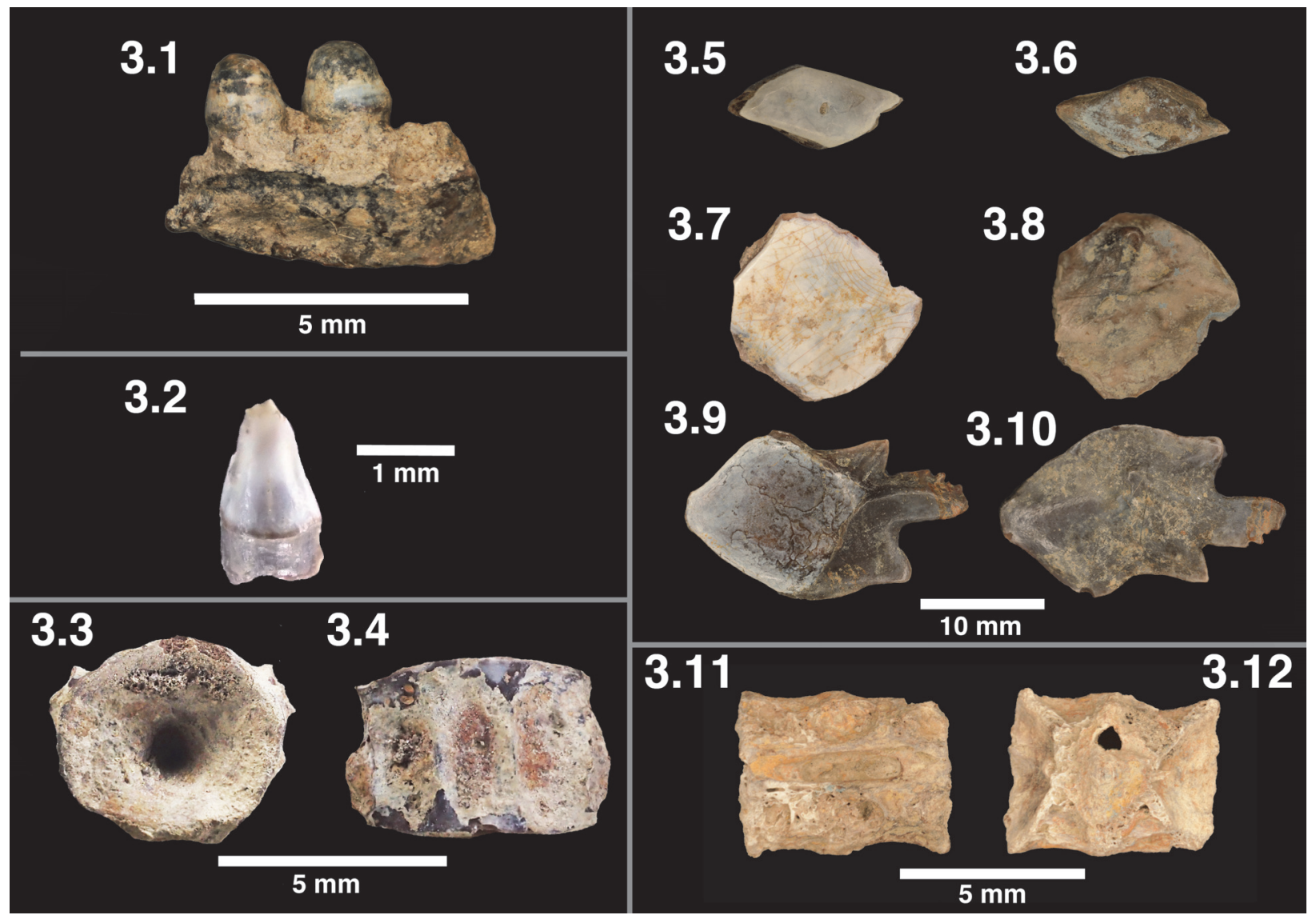

FIGURE 3. Fish material from the Arundel Clay. 3.1 USNM 521167, Lepidotes indet. jaw. 3.2 USNM 521169, Vidalamiinae tooth. 3.3 and 3.4 USNM 497787, amiiform vertebra in articular and ventral views. 3.5 and 3.6 USNM 497800, Holostei scale morphotype 1. 3.7 and 3.8 USNM 521146, Holostei scale morphotype 2. 3.9 and 3.10 USNM 521150, Holostei scale morphotype 3. 3.11 and 3.12 of USNM 497785, indeterminate teleost vertebra in ventral and dorsal views.

Material. Thirty-two ganoid scales, USNM 497788-497807 and 521140-521154.

Description and remarks. Three different ganoid scale morphotypes are present in the Arundel sample. Without articulated specimens, it is impossible to determine if these scales are from different species or represent different areas from a single type of fish.

Morphotype A includes diamond-shaped scales with no interlocking ball-and-socket joint (Figure 3.5 and 3.6). At least one specimen (USNM 497800) has an ovate foramen present, possibly representing passage of a nerve that originated from the lateral line. These scales are similar to those identified as Lepidotes by Brinkman et al. (2013, figure 10.4 C), Scale type A of Oreska et al. (2013), and Scale C of Kirkland (1998, figure 14 C). These scales are also the smallest of the three types we identify from the Arundel, none exceeding $10 \mathrm{~mm}$ in greatest length.
Scales referred to Morphotype B are small and subcircular to rectangular in outline (Figure 3.7-3.8). The external surface shows concentric rings. The inner surface bears a large, raised central peak that, together with a tab present on the outer surface, represents an interlocking joint. These scales are similar to scale type B of Oreska et al (2013).

Scales belonging to Morphotype $\mathrm{C}$ are the most complex and largest of the ganoid scales recovered from the Arundel Clay (Figure 3.9-3.10). These scales are roughly diamond-shaped, with three sharp tabs projecting from the anterior border. The anterior-dorsal tab fitted into a triangular groove on the medial-ventral side of the adjoining scale. The caudal border may have a wrinkled appearance and the external surface has multiple surface rings, similar to those of Morphotype B. Scales of this kind are similar to palaeoniscoid 
scales of Heckert (2004, figure 15E) and morphotype D of Oreska et al. (2013).

\section{TELEOSTEI Müller, 1846}

Figure 3.11-3.12

Material. A single incomplete vertebra, USNM 497785.

Description and remarks. We are unable to identify this highly-weathered vertebra, which is coated in mineral growth, beyond Teleostei indeterminate. The centrum has a long ventral foramen and is rostrocaudally elongate. It also has a parapophyseal foramen that is small and anteriorly located. This specimen compares favorably to clupeomorph centra of Brinkman et al. (2013, figure 10.18) and Morphoseries IIIA-1 of Neuman and Brinkman (2005, figure $9.8 G$ ).

ACTINOPTERYGII indet.

Material. Three partial teeth, USNM 521171521173.

Description and remarks. Teeth attributed to Actinopterygii indet. are all fragmentary and highly weathered. These teeth are most likely from one of the previously described taxa; however, the available pieces are too incomplete to identify with any confidence.

\section{Class SARCOPTERYGII Romer, 1955}

Subclass DIPNOI Müller, 1846

Order CERATODONTIDAE Gill, 1872

Genus CERATODUS Agassiz, 1838

Ceratodus kranzi Frederickson et al., 2016

Material. The holotype, USNM 508543, a partial pterygopalatine tooth plate, described by Frederickson et al. (2016).

Description and remarks. This large pterygopalatine tooth plate is superficially similar to those of $C$. robustus Knight, 1898 and C. frazieri Ostrom, 1970 in that all three are robust and possess a widecrushing surface. C. kranzi likely had five ridge crests and possesses a large convexity on the occlusal surface. This specimen as preserved measures $52 \mathrm{~mm}$ in its greatest dimension; as the top-quarter of the specimen is missing, this measurement is estimated to have exceeded $70 \mathrm{~mm}$ when complete. Based on a rough comparison with other lungfish, the size of this tooth plate would make $C$. kranzi one of the largest species in the aquatic ecosystem.

\section{Ceratodus sp.}

Material. Two tooth plates, USNM 521174 and 521175.

Description and remarks. Two small tooth plates are anatomically and taxonomically indeterminate, based on the likelihood that they represent juvenile individuals. The specimens are $\sim 5 \mathrm{~mm}$ in total length and lack the well-defined crushing platform seen in C. kranzi. Both specimens possess four ridge crests and have a surface texture typical of dipnoans. Based on the large amount of ontogenetic and intraspecific variation that is present in modern dipnoans (Kemp 1996, 1997), it is impossible to determine whether these plates represent upper or lower plates, or to determine their species. It could be that these specimens represent juvenile $C$. kranzi, but it is equally plausible that they represent a different species of dipnoan, as multiple species of lungfish commonly co-occur elsewhere in Jurassic and Cretaceous rocks of North America (Kirkland, 1987, 1998; Frederickson and Cifelli, 2017).

Class REPTILIA Linnaeus, 1758

TESTUDINATA Klein, 1751

Family PLEUROSTERNIDAE Cope, 1868

Subfamily GLYPTOPSINAE Marsh, 1890

Genus GLYPTOPS Marsh, 1890

Glyptops caelatus Hay, 1908

Figure 4.1

Material. Carapace fragments (17) probably pertaining to a single individual, USNM 497784.

Description and remarks. Multiple fragmentary shell pieces are most similar to those of Glyptops caelatus, named on the basis of several specimens collected by J.B. Hatcher at the Swampoodle site, Arundel Clay, in 1887 (Hay, 1908; Kranz, 1998b; figures $1 \mathrm{~A}-\mathrm{B})$. Ornamentation of the carapace fragments consists of an outer ring of irregular radiating grooves, directed proximally towards the center in all directions (Figure 4.1). The central area of the scutes have a similar texture, but with no apparent pattern. All of the recovered shell pieces were found in one place and suggest an animal of similar size, and they likely belong to the same individual.

\section{SOLEMYDIDAE Lapparent de Broin and Murelaga, 1996 \\ Genus NAOMICHELYS Hay, 1908 Naomichelys indet.}

Material. Shell fragments described by Kranz (1998b).

Description and remarks. Kranz (1998b) described two shell fragments collected at the Muirkirk site between 1989 and 1991. These specimens possess the characteristic shell pustules (papillae texture) of solemydid turtles (Joyce et al., 2014 and references therein). Kranz (1998b) tentatively attributed these fragments to Naomichelys 


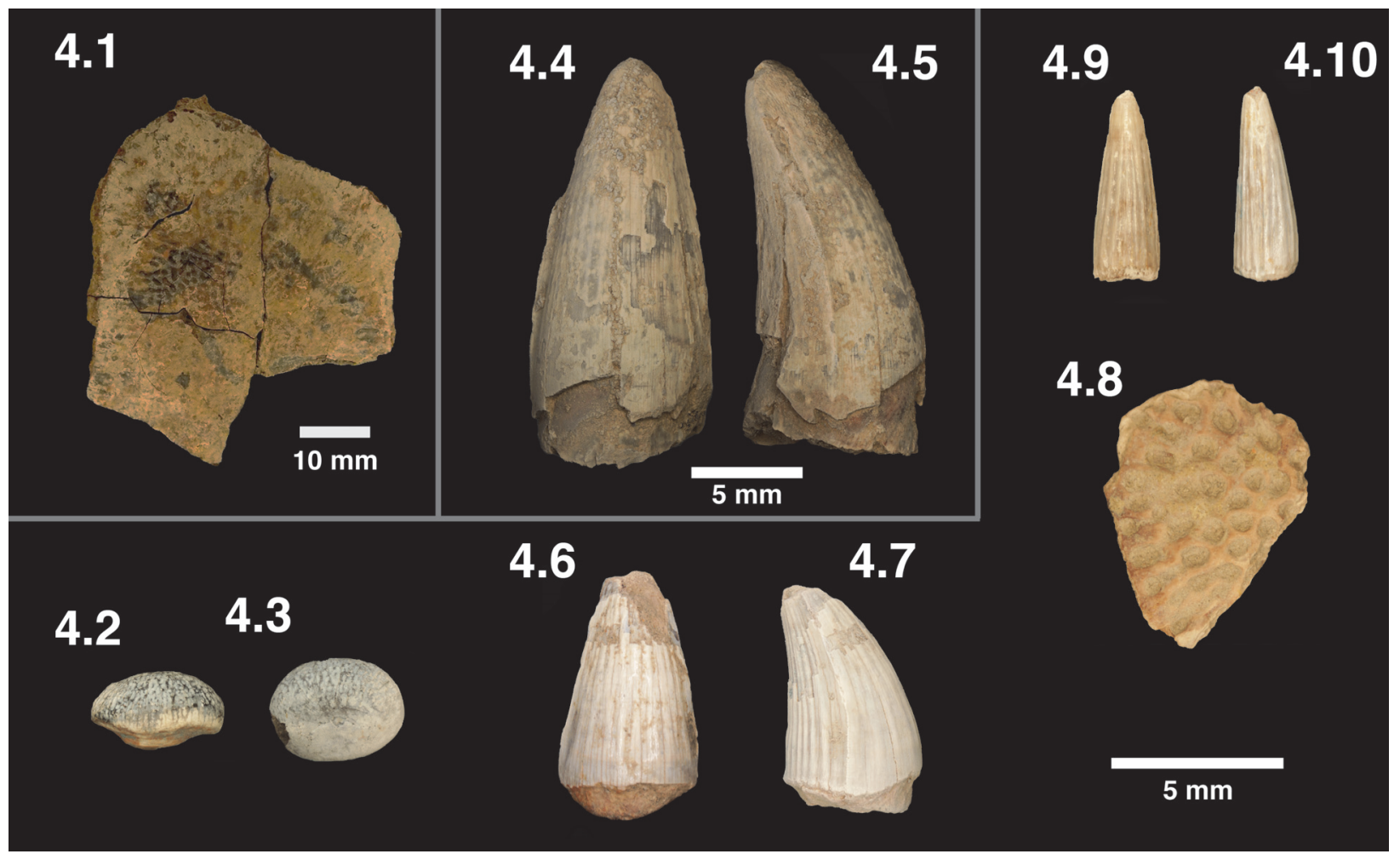

FIGURE 4. Testudines and crocodilians from the Arundel Clay. 4.1, USNM 497784, Glyptops caelatus shell fragment. 4.2 and 4.3 USNM 609376, cf. Bernissartiidae tooth. 4.4 and 4.5 USNM 609383, 4.6 and 4.7 USNM 609428, 4.8 USNM 609362, cf. Goniopholididae teeth and osteoderms. 4.9 and 4.10 USNM 609370, cf. Pholidosauridae tooth.

speciosa (Hay, 1908), a genus also known to occur in the Lower Cretaceous Cloverly and Kootenai Formations of Montana (Ostrom, 1970; Joyce et al., 2014), Antlers Formation of Oklahoma (Cifelli et al., 1997), and the Trinity Group of Texas (Langston, 1974; Joyce et al., 2014).

Genus ARUNDELEMYS Lipka et al., 2006

Arundelemys dardeni Lipka et al., 2006

Material. A single, incomplete skull lacking the lower jaws and cheek region, described by Lipka et al. (2006).

Description and remarks. The only known specimen of $A$. dardeni was found at the Muirkirk site and consists of a small, isolated skull. Though incomplete and lacking a shell, this skull is sufficient to identify it as a paracryptodiran based on a single foramen for the canalis caroticus internus, present midway along the basisphenoid. To date, there are no overlapping elements between the more common Arundel paracryptodiran Glyptops caelatus and $A$. dardeni, leaving open the possibility that these represent the same species.

\section{Nov. sp. indet.}

Material. a maxilla, articulated phalanges, and shell fragments described by Kranz (1998b).
Description and remarks. A partially articulated specimen from an unidentified turtle was first figured and partially described by Kranz (1998b). Even incomplete, this specimen is one of the bestpreserved specimens from the Muirkirk clay pit. Though this specimen still awaits formal description, Kranz (1998b) noted that its large size and relatively untextured shell likely points to the presence of a third turtle taxon in the Arundel Clay.

\footnotetext{
ARCHOSAURIA Cope, 1870

CROCODYLIFORMES Hay, 1930

NEOSUCHIA Benton and Clark, 1988

Family cf. BERNISSARTIIDAE Dollo, 1883

Gen. et. sp. indet.

Figure 4.2 and 4.3
}

Material. One complete and one partial molariform tooth (USNM 609376 and 609377).

Description and remarks. One small ovate tooth is referred to Bernissartiidae based on similarities with teeth from the Cloverly and Cedar Mountain formations (Fiorillo, 1999; Oreska et al. 2013; personal observation by JAF and RLC). Dendritic texture covers the occlusal surface and a small projection is present near the center of the root surface. Another similar, but larger, tooth (USNM 
609377 ) is missing most of the enamel on the crown and may also be allied to Bernissartiidae.

Family cf. GONIOPHOLIDIDAE Cope, 1875 Gen. et. sp. indet.

Figure 4.4-4.8

Material. Eleven scutes (USNM 609352-609362) and 78 complete and partial teeth (USNM 609387609455).

Description and remarks. Crocodyliform teeth make up the largest percentage of recognizable vertebrate fossils collected from the Muirkirk site in the Arundel Clay. These teeth range in length from $31 \mathrm{~mm}$ in the largest individuals to $4 \mathrm{~mm}$ in the smallest. Specimens included under this heading are conical or ovate in cross-section, possess moderately well-developed ridges as well as mesial-distal carinae, and most are slightly recurved, thus resembling goniopholidid teeth described from other Early Cretaceous formations of North America (Cifelli et al., 1997; Oreska et al., 2013). The osteoderms have typical crocodyliform scute morphology, wherein the outer side bears multiple subcircular and highly rounded pits that are intermittently spaced and variable in shape.

\section{Family cf. PHOLIDOSAURIDAE Zittel and} Eastman, 1902

Gen. et. sp. indet.

Figure 4.9-4.10

Material. Thirteen complete and partial teeth, USNM 609363-609375.

Description and remarks. Teeth that we provisionally refer to Pholidosauridae are very similar to those described from penecontemporaneous units elsewhere (Winkler et al., 1990; Fiorillo, 1999; Bonde, 2004). These teeth are tall, conical, coarsely striated with ridges, and bear well-defined carinae. We differentiate these teeth from those of other crocodyliforms based on their possession of a circular base, as compared to a more ovate base in other specimens. Striations are variable in appearance and range from deeply incised to relatively shallow. The largest pholidosaurid tooth is 13 $\mathrm{mm}$ tall; larger teeth may be present in the collection, but they are too similar to other crocodyliform teeth to differentiate qualitatively.

DINOSAURIA Owen, 1842

Order SAURISCHIA Seeley, 1887

Suborder THEROPODA Marsh, 1881

Family Carcharodontosauridae Stromer, 1931

Genus Acrocanthosaurus Stovall and Langston, 1950

Acrocanthosaurus sp.

Figure 5.1
Material. One complete tooth, USNM 497734; and four partial teeth, USNM 497732, 497735-497736, and 497741.

Description and remarks. These large, laterally compressed teeth are referred to Acrocanthosaurus sp. based on comparisons to specimens of Acrocanthosaurus atokensis from the Antlers Formation, Oklahoma (Lipka, 1998; personal observation by all authors). These specimens are generally large and recurved, with relatively fine denticulation (> 11 per $\mathrm{mm}$ ). The largest of the teeth measures $20 \mathrm{~mm}$ in fore-to-aft basal length (FABL of Farlow et al. 1991; Lipka, 1998), with a labio-lingual width of $11 \mathrm{~mm}$. These measurements are consistent with the size of other Acrocanthosaurus specimens from the Arundel Clay (Lipka, 1998). Harris (1998) hypothesized the presence of a second large theropod in the Arundel, based on a proximal caudal centrum said to differ from Acrocanthosaurus. Teeth included under this heading are sufficiently similar to those of Acrocanthosaurus atokensis to warrant placement in the same genus, at least.

TETANURAE Gauthier, 1986

ORNITHOMIMOSAURIA Barsbold, 1976 ORNITHOMIMOSAURIA INDET.

Material. Postcranial fossils described by Brownstein (2017).

Description and remarks. Known for over a century (Lull, 1911), ornithomimosaur material from the Arundel Clay has gone through dramatic reclassification over the decades (Gilmore, 1920; Russell, 1972; Smith and Galton, 1990; Makovicky, Kobayashi and Currie, 2004). Recent reevaluation of the available post-cranial record by Brownstein (2017), however, identified two different pedal morphs, implying the presence of at least two separate taxa in the unit. One is elongate and flattened as in derived ornithomimosaurs and ornithomimids, while the other is recurved and blunt, more similar to the condition in basal ornithomimosaurs. Since these interpretations are based on sparse material, we tentatively accept the identifications made by Brownstein (2017) without further comment.

\section{Family DROMAEOSAURIDAE Matthew and Brown, 1922 \\ Genus DEINONYCHUS Ostrom, 1969a Deinonychus sp. Ostrom, 1969a}

Figure 5.2

Material. Six complete and partial teeth, USNM 497742-497747.

Description and remarks. Teeth indistinguishable from those of Deinonychus antirrhopus from the Cloverly (Ostrom, 1969b) and Antlers (Brink- 


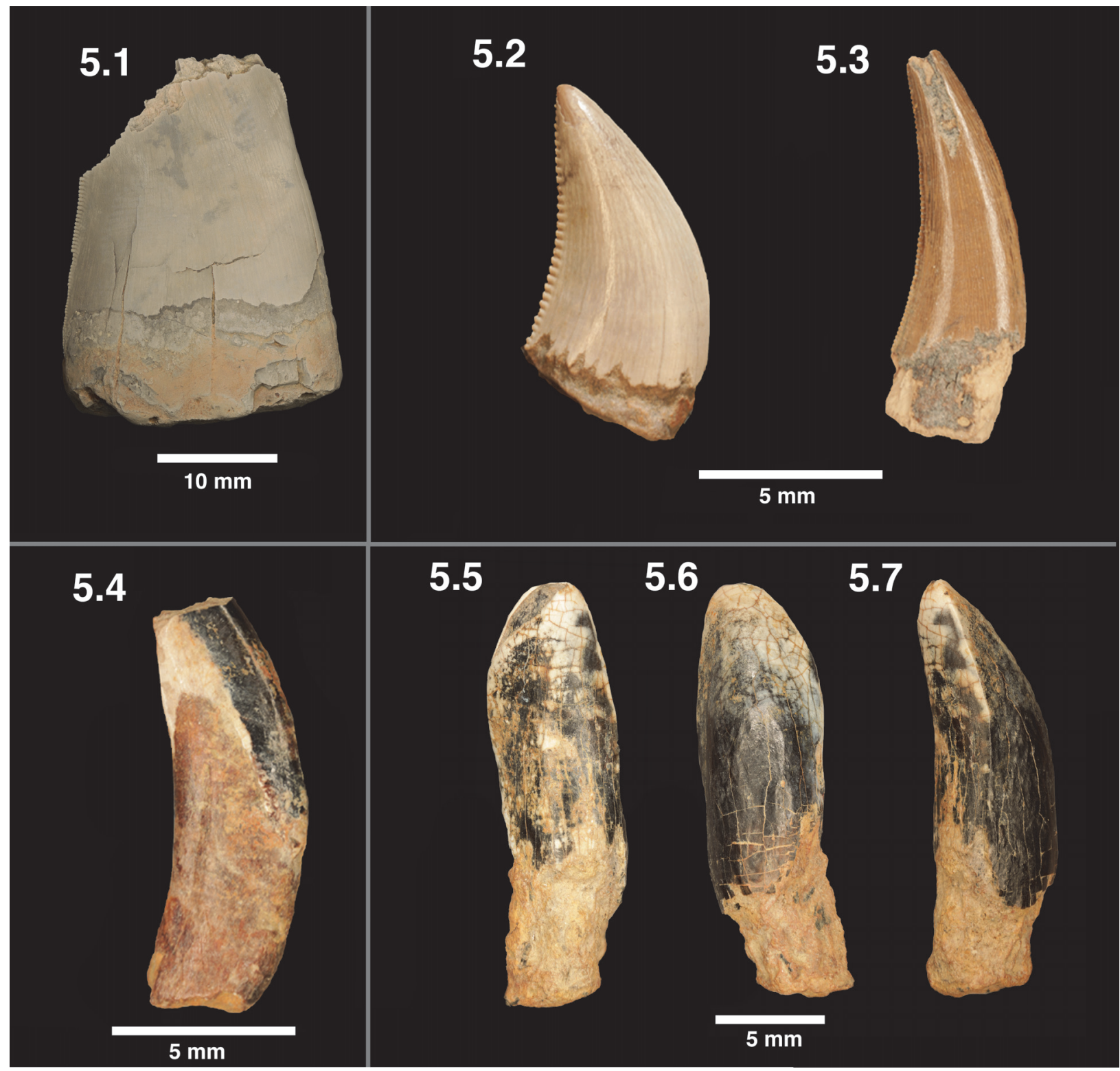

FIGURE 5. Saurischian dinosaur teeth from the Arundel Clay. 5.1 USNM 497732, Acrocanthosaurus sp.. 5.2 USNM 497743, Deinonychus sp.. 5.3 USNM 497748, aff. Richardoestesia. 5.4 USNM 497752, theropod indet.. 5.5-5.7 USNM 497763, Astrodon johnstoni.

man et al., 1998) formations are relatively abundant in the Arundel sample, and have been reported previously by Lipka (1998). These teeth are strongly recurved, laterally compressed, and possess denticles on both the mesial and distal margins, with the distal denticles being the larger of the two. Specimens vary in size and degree of recurvature, as well as the size and spacing between each denticle. These differences are herein conservatively attributed to their original differing positions in the jaw and differing ontogenetic age. Currently, tooth morphology alone is not suffi- ciently diagnostic to establish a species-level designation for theropods (Larson and Currie, 2013); however, the similarities between the teeth presented here and those of the Cloverly and Antlers formations would indicate the presence of $D$. antirrhopus or of a closely related species of dromaeosaurid in the Arundel Clay.

\section{THEROPODA indet. A aff. Richardoestesia sp.} Figure 5.3

Material. Two teeth, UNSM 497748-497749. 
Description and remarks. Two small teeth are here referred to Theropoda indet. A based on their unique combination of features that distinguish these teeth from those of Deinonychus sp. These teeth range from 5-11 mm in height and maximum widths of 2-4 mm. Denticles are present on both mesial and distal margins but the mesial denticles appear to be smaller. The teeth are mesiodistally thinner than those attributed to Deinonychus sp. and possess much smaller denticles on both margins. Further, the general curvature of the teeth is different, in that teeth from Theropoda indet. A are more evenly curved, while those of Deinonychus sp. have a straight base and curve more sharply higher up the tooth. These teeth are similar to those reported elsewhere as Richardoestesia (Oreska et al., 2013, Theropoda indet. Species A; Eaton et al., 2014, figure 8D).

\section{THEROPODA INDET.}

Figure 5.4

Material. Four partial teeth (USNM 497750497753), seven fragmentary bones (USNM 497754-497759).

Description and remarks. Theropod teeth that were highly weathered and abraded were indeterminate, based on their incompleteness. All of the teeth are small (less than $15 \mathrm{~mm}$ long) and are missing most of their enameled surface. Multiple fragmentary and abraded metapodial ends and undiagnostic other elements are also present in the Arundel sample. These specimens are referred to Theropoda based on their hollow interiors and well-developed collateral ligament pits.

Suborder SAUROPODOMORPHA von Huene, 1932

Family incertae sedis

Genus ASTRODON Leidy, 1865

Astrodon johnstoni Leidy, 1865

Figure 5.5-5.7

Material. Fifteen complete or partial teeth, USNM 497760-497774.

Description and remarks. Tall and rounded sauropod teeth up to $20 \mathrm{~mm}$ in height are herein referred to Astrodon johnstoni. Most teeth are relatively thin and possess a triangular crown that comes to a rounded apex at the top of the tooth. Teeth of this kind were the first vertebrate fossils described from the Arundel Clay and among the most frequently encountered fossils from the Potomac Formation (Kranz, 1989). Carpenter and Tidwell (2005) analyzed much of the known sauropod skeletal material from the Arundel and concluded that there was a single diagnosable sauropod from the formation based on the low anatomical variability of the sample. However, D'Emic (2012) argues that many of the characters used in this study are also found in other sauropods or are related to the juvenile status of many of the specimens. Further, the teeth of $A$. johnstoni are not diagnostic at a specific or generic level and the few bones that are diagnostic, are not in articulation and cannot be demonstrated to belong to the same species as the teeth. D'Emic (2012) concludes that A. johnstoni (and its probable synonyms, Pleurocoelus nanus Marsh, 1888; and $P$. altus Marsh, 1888) must be regarded as nomina dubia based on the lack of autapomorphies present in the holotype material. Here, $A$ johnstoni is retained for historical consistency only.

ORNITHISCHIA Seeley, 1887

NEOCERATOPSIA Sereno, 1986

Fam., gen., and sp. indet.

Figure 6.1-6.3

Material. One tooth, USNM 497783.

Description and remarks. USNM 497783 is most similar to those of Neoceratopsia indet. gen. and sp. of Chinnery et al. (1998), most notably USNM 337977. These teeth are leaf-shaped in lateral view, with a tall and pointed apex in the center that slopes to about halfway down the crown. The tooth possesses a large primary ridge that extends to the base of the crown on the labial side of the tooth. Secondary ridges are also present, with three large ridges that grade into smaller ridges on the crown's lateral border. The tooth described here favorably matches the description by Chinnery et al. (1998), and further documents the presence of at least one species of neoceratopsian in the Potomac Formation.

\author{
ANKYLOSAURIA Osborn, 1923 \\ Family incertae sedis \\ Genus PRICONODON Marsh, 1888 \\ Priconodon crassus Marsh, 1888 \\ Figure 6.4
}

Material. Three complete or partial teeth, USNM 497775-49777.

Description and remarks. Teeth attributed to $P$. crassus are identified as ankylosaurian based on their triangular shape in lateral view, basal cingulum, and laterally compressed crown with apical denticulate carinae. The number of denticles varies between teeth, ranging from 9-11. These teeth also vary in size and shape, with the tallest being the most rounded and recurved and the shortest being the most laterally compressed and straightest. Teeth are referred to Priconodon crassus 


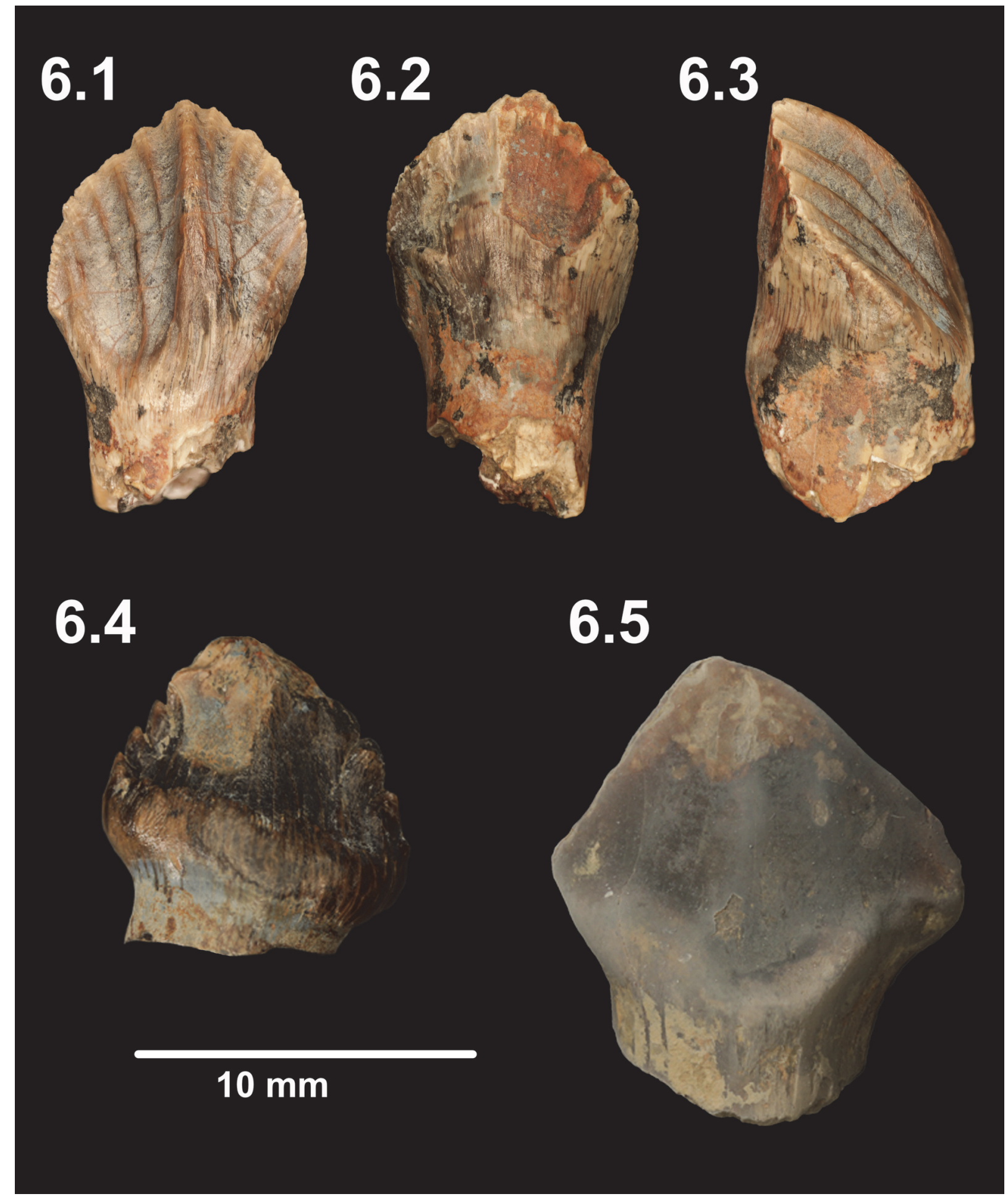

FIGURE 6. Ornithischian dinosaur teeth from the Arundel Clay. 6.1, 6.2, and 6.3 USNM 497783, basal neoceratopsian. 6.4 USNM 497777, Priconodon crassus. 6.5 USNM 497732, an indeterminate ankylosaur. 
based on their similarity to the holotype specimen (USNM 2135) described by Marsh (1888: figures 79). Though morphologically similar to most ankylosaurian teeth, Carpenter and Kirkland (1998) diagnosed $P$. crassus as a tentatively valid genus and species based on large tooth size and a suite of characters, relating to the cingulum and denticles that cannot be seen together in other taxa.

\section{?ANKYLOSAURIA}

Fam., gen. and sp. indet.

Figure 6.5

Material. Five complete or partial teeth, USNM 497778-497782.

Description and remarks. Teeth included under this heading are similar to those described above as belonging to Priconodon crassus but are generally larger and lack well-defined denticles. All five teeth are weathered or fragmentary, making it difficult to compare these specimens completely. These teeth tend to be more labiolingually compressed and lower crowned than those described for $P$. crassus. The teeth possess a single primary cusp; secondary ridges or other adornments could have been present but obliterated by attrition, or by weathering or other post-mortem process. These specimens obviously belong to an ornithischian dinosaur, but beyond this their affinities are problematic. We provisionally assign them to Ankylosauria on the basis of their similarity to teeth of Priconodon.

MAMMALIA Linnaeus, 1758

EUTRICONODONTA Kermack, Mussett, and Rigney, 1973

Family TRICONODONTIDAE Marsh, 1887

Subfamily ALTICONODONTINAE Fox, 1976 Genus ARUNDELCONODON Cifelli, Lipka, Schaff, and Rowe, 1999

Arundelconodon hottoni Cifelli, Lipka, Schaff, and Rowe, 1999

Material. The holotype, USNM 497729, a right dentary bearing the last two premolars (p3-4?) and $\mathrm{m} 1-3$, described by Cifelli et al. (1999). An edentulous right dentary described by Rose et al. (2001), USNM 497730, is also likely referable to the species.

Description and remarks. The dentary differs from other Alticonodontinae in the presence of Meckel's groove on its lingual side. The dental formula is unknown, although a premolar count of four seems likely (Rose et al., 2001). The last two premolars resemble those, where known, for other triconodontids: they bear four cusps and are asymmetrical in lateral view, with a basally-placed cusp b, a tall, posteriorly-inclined cusp a, cusp c on the distal flank of cusp a about halfway down, and a small, basally placed and posteriorly projecting $d$ cusp (cusp terminology follows Crompton and Jenkins, 1968). As is generally the case, the last two premolars are considerably higher-crowned than the molars, and are subequal to them in anteroposterior length. The molars resemble those of other Alticonodontinae (Cifelli and Madsen, 1998; Cifelli et al. 1998) in having tall, posteriorly curved and subequal cusps a-c and well-developed interlocking tongue-and-groove structures present on roots. Lower molars of Arundelconodon differ from those of other alticonodontines in having a much smaller $\mathrm{d}$ cusp and a weaker lingual cingulum.

Considering the general preservation of vertebrate fossils from the Arundel Clay, discovery of the holotype-one of the most complete triconodontid specimens known from the Cretaceous of North America-was a surprising and welcome addition to knowledge. Arundelconodon is rather similar to other alticonodontines from the late Early and early Late Cretaceous (Patterson, 1951; Turnbull and Cifelli, 1999; Cifelli and Madsen, 1998; Cifelli et al., 1998), such as Astroconodon (AptianAlbian, Texas, and Oklahoma; Albian-Cenomanian, Utah), Corviconodon (Albian-Cenomanian, Utah, Montana) and Jugulator (Albian-Cenomanian, Utah), differing in the retention of a few plesiomorphies (such as the slight development of lower molar cusp d).

MULTITUBERCULATA Cope, 1884

"PLAGIAULACIDA" Ameghino, 1889

Family uncertain

Genus ARGILLOMYS Cifelli, Gordon, and Lipka, 2013

Argillomys marylandensis Cifelli, Gordon, and Lipka, 2013

Material. Only the holotype, USNM 497739, an isolated left M2, described by Cifelli et al. (2013).

Description and remarks. This molar resembles some "plagiaulacidans" (we cite the name in quotes because it represents a paraphyletic assemblage; see Kielan-Jaworowska and Hurum, 2001) in that it bears surface ornamentation in the form of ribs and grooves, lacking pits. Cusps of the lingual row are distinct, with well-separated bases, not united into a ridge, and with recognizable valley floors. Argillomys is distinct from most comparable taxa in having an enlarged second cusp in the buccal row, high length to width proportions, and in the central placement of the last cusp in the lingual row. 
Affinities of Argillomys are uncertain owing to its retention of many plesiomorphic states. Cifelli et al. (2013) recognized it as a late-surviving relative of one of several "plagiaulacidans" groups typical of the Late Jurassic or earliest Cretaceous. Intriguingly, closest similarity is to an unnamed taxon of Paulchoffatiidae, a group known mainly from the Kimmeridgian-age Guimarota beds of Portugal.

\section{DISCUSSION}

\section{Taphonomy and Faunal Comparison}

This sample of fossils from USNM locality 41614 is largely composed of the most resistant skeletal elements. Teeth comprise the vast majority of the specimens, followed in abundance by scales, bones, and scutes. All specimens are disarticulated; however, abrasion is minimal on most specimens, suggesting that there was little transportation prior to burial. Specimens range in size from less than $1 \mathrm{~mm}$-tall in semionotid fish teeth to a $37 \mathrm{~mm}$-tall Acrocanthosaurus tooth. Larger skeletal elements described elsewhere are also known from the Arundel Clay (Marsh, 1888; Gilmore, 1921), but most are similarly disarticulated. Nonvertebrate fossils are abundant, including a variety of plant material and internal molds from gastropods and bivalves.

Within major taxonomic groups, the vertebrate fauna of the Arundel Clay compares favorably at the family and/or genus level with assemblages from contemporaneous formations of central and western North America. The Arundel contains two hybodont sharks, Egertonodus basanus and Hybodus ensis. Of these, E. basanus has been previously reported from England, Germany, Spain, and western North America, while $H$. ensis is only known from England (Underwood and Reese, 2002). Hybodonts from the Cloverly include $E$. basanus but not $H$. ensis; the Antlers Formation lacks both species entirely, with identifiable Hybodus specimens belonging to $H$. butleri (Thurmond, 1971; Winkler et al., 1990; Cifelli et al., 1997; though $H$. butleri instead may belong to a different genus, Meristodonoides Underwood and Cumbaa, 2010). This shark distribution suggests an intriguing link of the Arundel fauna to that of the Wealden. So far as known, most Arundel genera of bony fishes (Lepidotes, Ceratodus), turtles (Glyptops, Naomichelys), and dinosaurs (Deinonychus, Acrocanthosaurus; Cifelli et al., 1997; Kirkland et al., 1999; Oreska et al., 2013) are typical of North American Aptian-Albian assemblages. It is worth noting, however, that except for the sharks (which probably were salt-water tolerant and hence broadly distributed), all taxa identified to the species level are endemic to the Arundel, as is one genus of turtle (Arundelmys), the two genera of mammals (Arundelconodon, Argillomys), and possibly the ankylosaur Priconodon. The dinosaur assemblage from the Arundel Clay deserves an additional comment: sauropods (mostly apparent juveniles) and ankylosaurs comprise $50 \%$ of identified dinosaur specimens. This contrasts with their scarcity in comparably-aged rock units of North America (for example, the Antlers of Oklahoma, where there are no ankylosaurs and sauropods make up no more than $3 \%$ of dinosaur specimens; JAF, unpublished data). Elsewhere in the mid-Cretaceous of North America, ornithopods predominate. Indeed, the basal iguanodontian Tenontosaurus is so abundant in the Antlers (Oklahoma) and Cloverly (Wyoming, Montana) formations as to suggest a diluvial event. Data in hand do not suggest a reason for this anomaly; perhaps the only hypothesis that can be readily dismissed at present-and for obvious reasons-is collecting bias. Tracks attributed to Ornithopoda are reported to be abundant in the Patuxent facies (which underlies the Arundel) of Virginia (Weems and Bachman, 2015).

As a whole, the vertebrate fauna of the Arundel Clay (Table 1) is less diverse than assemblages from contemporaneous units. Undoubtedly, this is partly the result of limited sampling: far fewer fossils are known from the Arundel (Figure 7), and they were collected from a few sites representing a single facies and depositional environment. Also, few of the Arundel specimens are identifiable below the family level. Nonetheless, abundance data are sufficient to show that the Arundel fauna is unique in its composition when compared to the assemblages from the Antlers and Cloverly formations. Among the most common taxa, crocodilians and chondrichthyans are more numerous than freshwater fishes, which are relatively the most common faunal group in both the Cloverly and Antlers formations. Though caution should be taken when comparing these different sites, ecological differences may not be too surprising given the geographic and environmental differences between the Atlantic coastal fauna and those of the Western Interior.

\section{Depositional Environment}

Clark and Bibbins (1897) published one of the first systematic geologic studies of the Potomac Formation (recognized by them as a group), in 
TABLE 1. Species list for the Arundel Clay. * indicates species not observed here, but published elsewhere. Species data from Marsh (1888), Gilmore (1921), Chinnery et al. (1998), Harris (1998), Kranz (1998a,b), Lipka (1998), Cifelli et al. (1999), Lipka et al. (2006), Cifelli et al. (2013), Frederickson et al. (2016), and Brownstein (2017).

\begin{tabular}{|c|c|c|c|c|}
\hline Fauna List & & & & \\
\hline Vertebrata & indet. & & & multiple \\
\hline \multirow[t]{10}{*}{ Actinopterygii } & Osteichthyes & indet. & & 3 \\
\hline & Holostei & indet. & Scale 1 & 7 \\
\hline & & & Scale 2 & 7 \\
\hline & & & Scale 3 & 2 \\
\hline & & & indet. & 16 \\
\hline & & Lepidotes & morph 1 & 10 \\
\hline & & & morph 2 & 3 \\
\hline & & Amiiformes & indet. & 2 \\
\hline & & Vidalamiinae & sp. & 4 \\
\hline & Teleostei & indet. & sp. & 1 \\
\hline \multirow[t]{2}{*}{ Sarcopterygii } & Dipnoi & Ceratodus & kranzi & 1 \\
\hline & & & indet. & 2 \\
\hline \multirow[t]{4}{*}{ Chondrichthyes } & & Hybodus & ensis & 15 \\
\hline & & Egertonodus & basanus & 17 \\
\hline & & Hybodontidae & indet & 49 \\
\hline & & Hybodontoidea & indet. & 6 \\
\hline \multirow[t]{14}{*}{ Archosauria } & Crurotarsi & Pholidosauria & indet. & 13 \\
\hline & & Crocodyliformes & indet. & 89 \\
\hline & & Bernissartiidae & indet. & 2 \\
\hline & Dinosauria & Acrocanthosaurus & sp. & 2 \\
\hline & & Large theropod & indet. & * \\
\hline & & aff. Richardoestesia & sp. & 2 \\
\hline & & Deinonychus & sp. & 5 \\
\hline & & $\begin{array}{l}\text { Ornithomimosaur } \\
\text { Ornithomimosaur }\end{array}$ & $\begin{array}{l}\text { indet. } \\
\text { indet. } 2\end{array}$ & * \\
\hline & 冫 & Theropoda & indet. & 14 \\
\hline & & Astrodon & johnstoni & 16 \\
\hline & & Ornithopoda & indet & * \\
\hline & & basal Neoceratopsia & indet. & 1 \\
\hline & & Priconodon & crassus & 4 \\
\hline & & ?Ankylosauria & indet. & 4 \\
\hline \multirow[t]{4}{*}{ Chelonia } & & Glyptops & caelatus & 1 \\
\hline & & Naomichelys & speciosa & * \\
\hline & & Arundelemys & dardeni & * \\
\hline & & nov. & sp. & * \\
\hline \multirow[t]{2}{*}{ Mammalia } & Triconodontidae & Arundelconodon & hottoni & * \\
\hline & Multituberculata & Argillomys & marylandensis & * \\
\hline
\end{tabular}

which they viewed the Arundel as part of an ancient valley with low sedimentation rates and abundant swamp flora. Hansen (1969) upheld this interpretation while reconstructing the different depositional environments of the Potomac. In this reconstruction, the Arundel Clay was seen as representing a fringe swamp or paludal environment, formed by the relative rise of the water table during a transgressive sequence. (Clark and Bibbins, 1897 , p. 496 had postulated complex and partly 


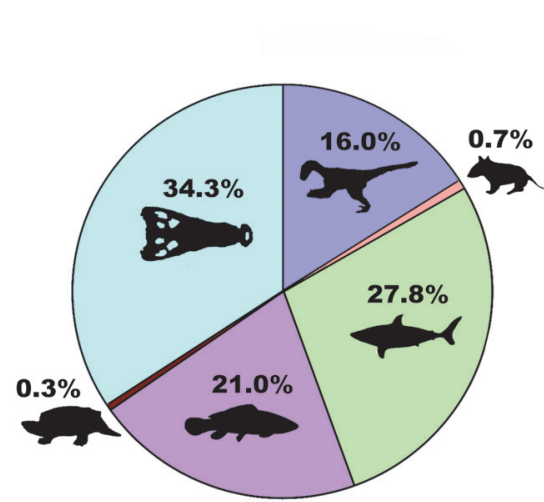

ARUNDEL

$\mathbf{n}=\mathbf{3 0 8}$

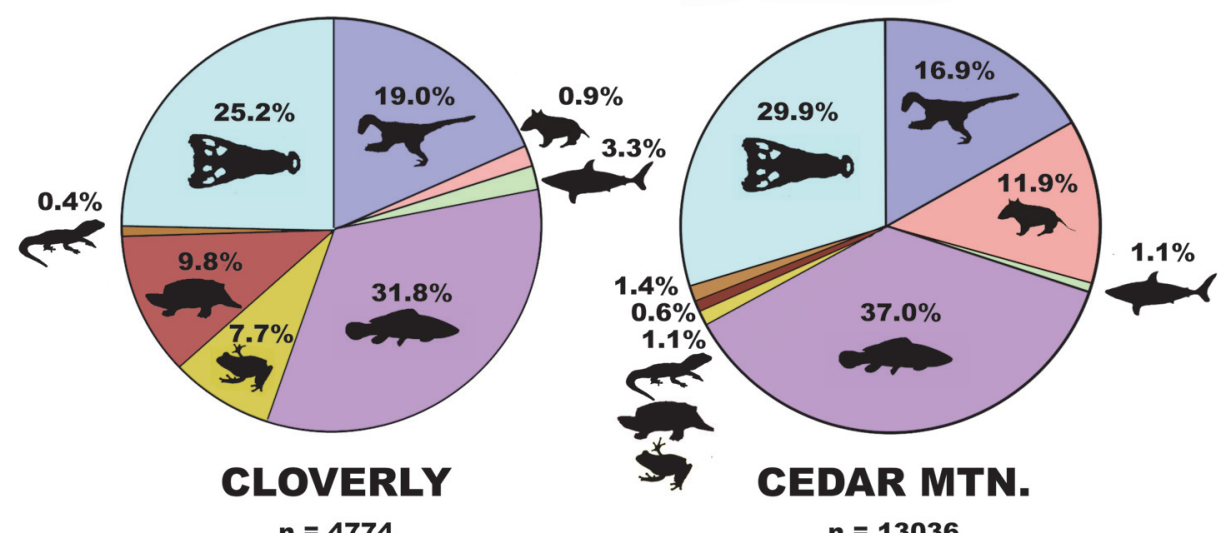

$n=\mathbf{4 7 7 4}$

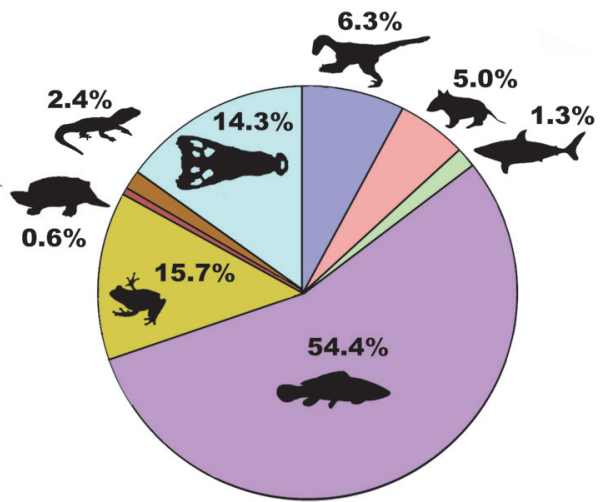

ANTLERS

$n=\mathbf{4 7 6 3}$

$n=13036$

FIGURE 7. Pie charts showing the faunal assemblages for mid-Cretaceous formations of North America; Arundel Fm. from this study, Antlers Fm. from the OMNH collections, Cloverly Fm. from Oreska et al. (2013) and the OMNH collections, and Cedar Mountain Formation from Goldberg (2000).

contradictory changes to explain the Potomac sequence, including simultaneous elevation of deposits-to account for the shift from nearshore marine deposition in the Patuxent, to terrigenous in the Arundel-coupled with "landward depression of the continental border" to explain the character of Arundel sediments.) Kraft et al. (1971) similarly hypothesized a swamp origin for the Arundel Clay, based on its limited sand content $(20 \%)$ as compared to that of braided river systems (at least $50 \%$ ). More recently, the depositional environment of the Arundel Clay facies was reinterpreted as representing an ancient floodplain, with fossils preserved within the lignitic muds that filled abandoned channels and oxbow lakes. Kranz (1998a) observed that the fossiliferous parts of the Arundel are comprised almost entirely of silt and clays that are often found within U- or V-shaped profiles with varying depths and lengths. This infilled-channel interpretation has since been repeated, in multiple publications, as the leading explanation for the preservation of the Arundel fauna (e.g., Lipka et al., 2006; Stanford et al., 2011; Frederickson et al., 2016).

In light of our additions to and re-study of the vertebrate fauna, we hypothesize a slightly different depositional setting: that the Arundel represents a near-coastal environment, probably within a paludal or swamp system that may have been ephemerally brackish. This interpretation is similar to that of Hansen (1969), who interpreted the Arundel facies as part of a transgressive sequence wherein a relative rise in sea level brought marsh or swamp environments more inland. Because sedimentary structures indicative of tidal influence (e.g., tidal rhythmites) are unknown at the Muirkirk site, we interpret the Arundel as a supratidal environment on the proximal 
end of the deltaic plain. This environment would have been unaffected by regular tidal fluctuations, but likely received periodic saline floods from extreme high tides and storm surges.

Evidence for coastal influence has been noted throughout the Potomac. For example, Groot (1955) observed the presence of pyrite within the undifferentiated lower Potomac of Delaware, and suggested that this could be an indicator of brackish water, because freshwater rarely contains enough sulfur to form pyrite (however, pyrite can form in other environments as well; see Harmsen, 1954). Similarly, mechanical analyses of these same sediments show a range in proportions of different particle sizes, but most have a ratio of silt to mud consistent with modern brackish water environments (Groot, 1955). Moreover, Glaser (1967) and Hansen (1969) both hypothesized a lateral marine facies equivalent to the east of the exposed lower Potomac Formation. Evidence for a local marine deposit was found in the form of marine invertebrates from drill cores in eastern Maryland, dating from the Albian to Cenomanian (Glaser, 1967). Further, Reinhardt et al. (1980) noted the presence of presumably marine glauconite in the Oak Grove core of Virginia occurring within pollen zone I, which Brenner (1963) correlated with the Arundel Clay.

Biologically, the vertebrate fauna of the Arundel supports a near-coastal origin for the deposits. Hybodont sharks and goniopholidid crocodylomorphs dominate the fauna, comprising some $58 \%$ of specimens. Although the salt-tolerance of goniopholidids is unknown, hybodonts were likely diadromous, as teeth and spines from this group are regularly found in both marine and terrestrial deposits (e.g., Fischer, 2008). A comparison with roughly contemporaneous terrestrial formations from western North America shows that the Arundel far exceeds the typical relative abundance of chondrichthyans for the Aptian-Cenomanian (Figure 7). The Arundel has at least one species of Ceratodus, a genus known to occur in both terrestrial and nearshore deposits (Schultze, 1981; Kirkland, 1987; Frederickson and Cifelli, 2017). Indeed, many of the groups represented in the Arundel assemblage, such as hybodonts, crocodilians, and ceratopsians, show affinities for coastal settings in other rock units (Brinkman, 1990; Brinkman et al., 2005).
The most conspicuous faunal evidence for a near-coastal environment is the complete absence of lissamphibians. Living forms (frogs, salamanders, and caecilians) are normally salt intolerant, with only a few species possessing the highlyderived adaptations needed to survive in salinerich environments (Rios-López 2008). In the Antlers, Cloverly, and Cedar Mountain formations, Lissamphibia represent a small but consistent element of the fauna, and include albanerpetontids, anurans, and caudatans (Cifelli et al., 1997, Oreska et al., 2013). Although lacking in the Arundel, amphibians were present elsewhere in the Potomac environment, as exemplified by anuranlike tracks in the Patuxent facies of Virginia (Weems and Bachman, 1997, 2015). The presence of frogs in the Patuxent, but not in the Arundel, supports the hypothesis that the Arundel represents an environment inhospitable to this group, albeit from negative evidence. Similarly, the absence of frogs and salamanders contradicts an inland oxbow reconstruction of the Arundel, as oxbow lakes are often ideal preservational environments for fragile lissamphibian bones. For example, in an oxbow deposit from the Late Cretaceous Mussentuchit Member of the Cedar Mountain Formation, lissamphibians comprise up to $12 \%$ of the entire fauna (Goldberg, 2000). Similarly, composite data from multiple sites in the same formation yield amphibians at smaller, but nonetheless detectable abundances ( 1.1\%) (Figure 7; Goldberg, 2000). Though we believe that the Arundel was deposited near the ancient Atlantic coastline, we acknowledge that, to date, no obligate marine flora or fauna has been recovered from the Arundel Clay at Dinosaur Park. We interpret these missing elements as an indication that marine input into the Arundel ecosystem was minimal.

\section{CONCLUDING REMARKS}

The Arundel Clay at Dinosaur Park represents a rare glimpse into the terrestrial fauna of the American eastern seaboard during the Early Cretaceous. Unfortunately, due to expansive construction over the last two centuries, Dinosaur Park is one of the few outcrops of the Arundel Clay still in existence. Though our sample from the Muirkirk site is small, we hope that it may foster comparative studies between the Arundel and other Early Cretaceous formations. If nothing else, this study emphasizes the need to recover a better fossil 
record from the Early Cretaceous of the eastern seaboard.

\section{REFERENCES}

Agassiz, L. 1832. Untersuchungen über die fossilien Fische der Lias-formation. Jahrbuch für Mineralogie, Geognosie Geologie und Petrefaktenkunde, 3:139-149.

Agassiz, L. 1833. Recherches sur les Poissons fossiles (1e livraison). Imprimerie de Petitpierre, Neuchâtel.

Agassiz, L. 1833-44. Recherches sur les Poisson fossiles. Imprimerie de Petitpierre, Neuchâtel.

Agassiz, L. 1837. Recherches sur les Poissons fossiles (8-9e livraisons). Imprimerie de Petitpierre, Neuchâtel.

Agassiz, L. 1838. Recherches sur les Poissons fossiles (11e livraison). Imprimerie de Petitpierre, Neuchâtel.

Agassiz, L. 1843. Recherches sur les Poissons fossiles (15e-16e livraisons). Imprimerie de Petitpierre, Neuchâtel.

Ameghino, F. 1889. Contribución al conocimiento de los mamíferos fósiles de la República Argentina. Actas de la Academía Nacional de Ciencias de Córdoba, 6:1-1027.

Arambourg, C. and Bertin, L. 1958. Super-ordres des holostéens et des halecostomes (Holostei et Halecostomi), p. 2173-2203. In Grassé, P. (ed.), Traité de Zoologie. Masson et Cie, Paris.

Barsbold, R. On a new Late Cretaceous family of small theropods (Oviraptoridae fam. n.) of Mongolia. Doklady Akademia Nauk SSSR, 226:685-688.

Benton, M.J. and Clark, J.M. 1988. Archosaur phylogeny and the relationships of the Crocodylia, p. 295-338. In Benton, M.J. (ed.), The Phylogeny and Classification of the Tetrapoda, Volume I: Amphibians, Reptiles, Birds. Systematics Association Special Volume 35A. Clarendon Press, Oxford.

Bilelo, M.M. 1969. The fossil fish Lepidotes in the Paluxy Formation, north-central Texas. American Midland Naturalist, 81:405-411. https://doi.org/10.2307/2423980

Bonaparte, C.L. 1838. Synopsis vertebratorum systematis. Nuovi Annales delle Scienze Naturali, 2:105-133.

Bonaparte, C.L. 1841. Iconografia della Fauna Italica per le Quattro Classi degli Animali Vertebrati, Volume 3: Pesci. Introduzione. Salviucci, Rome.

Bonde, N. 2004. An Early Cretaceous (Ryazanian) fauna of "Purbeck-Wealden type" at Robbedale, Bornholm, Denmark, p. 507-528. In Arratia, G. and Tintori, A. (eds.), Mesozoic Fishes 3: Systematics, Paleoenvironments and Biodiversity. Verlag Dr. Friedrich Pfeil, Munich.

Brenner, G.J. 1963. The spores and pollen of the Potomac Group of Maryland. Maryland Department of Geology, Mines, and Water Resources Bulletin, 27:1-215.

Brinkman, D.B. 1990. Paleoecology of the Judith River Formation (Campanian) of Dinosaur Provincial Park, Alberta, Canada: evidence from vertebrate microfossil localities. Palaeogeography, Palaeoclimatology, Palaeoecology, 78:37-54. https://doi.org/10.1016/ 0031-0182(90)90203-j

Brinkman, D.L., Cifelli, R.L., and Czaplewski, N.J. 1998. First occurrence of Deinonychus antirrhopus (Dinosauria: Theropoda) from the Antlers Formation (Lower Cretaceous: AptianAlbian) of Oklahoma. Oklahoma Geological Survey, 146:1-27.

Brinkman, D.B., Newbrey, M.G., Neuman, A.G., and Eaton, J.G. 2013. Freshwater Osteichthyes from the Cenomanian to late Campanian of Grand Staircase-Escalante National Monument, Utah. In Titus, A.L. and Loewen, M.A. (eds.), At the Top of the Grand Staircase: The Late Cretaceous of Southern Utah. Indiana University Press, Bloomington.

Brinkman, D.B., Russell, A.P., and Peng, J-H. 2005. Vertebrate microfossil sites, p. 88-97. In Currie, P.J. and Koppelhus, E.B. (eds.), Dinosaur Provincial Park: A Spectacular Ancient Ecosystem Revealed. Indiana University Press, Bloomington.

Brownstein, C.D. 2017. Description of Arundel Clay ornithomimosaur material and a reinterpretation of Nedcolbertia justinhofmanni as an "ostrich dinosaur": biogeographic implications. PeerJ, 5:e3110. https://doi.org/10.7717/peerj.3110

Carpenter, K. and Kirkland, J.I. 1998. Review of Lower and middle Cretaceous ankylosaurs from North America. New Mexico Museum of Natural History and Science Bulletin, 14:249-270. 
Carpenter, K. and Tidwell, V. 2005. Reassessment of the Early Cretaceous sauropod Astrodon johnstoni Leidy 1865 (Titanosauriformes), p. 78-114. In Tidwell, V. and Carpenter, K. (eds.), Thunder Lizards: the Sauropodomorph Dinosaurs. Indiana University Press, Bloomington.

Chinnery, B., Lipka, T.R., Kirkland, J.I., Parrish, J.M., and Brett-Surman, M. 1998. Neoceratopsian teeth from the Lower to middle Cretaceous of North America. New Mexico Museum of Natural History and Science Bulletin, 14:297-302.

Cifelli, R.L., Gardner, J.D., Nydam, R.L., and Brinkman, D.L. 1997. Additions to the vertebrate fauna of the Antlers Formation (Lower Cretaceous), southeastern Oklahoma. Oklahoma Geology Notes, 57(4):124-131.

Cifelli, R.L., Gordon, C.L., and Lipka, T.R. 2013. New multituberculate mammal from the Early Cretaceous of eastern North America. Canadian Journal of Earth Sciences, 50:315-323. https://doi.org/10.1139/e2012-051

Cifelli, R.L., Lipka, T.R., Schaff, C.R., and Rowe, T.B. 1999. First Early Cretaceous mammal from the eastern seaboard of the United States. Journal of Vertebrate Paleontology, 19:199-203. https://doi.org/10.1080/02724634.1999.10011134

Cifelli, R.L. and Madsen, S.K. 1998. Triconodont mammals from the medial Cretaceous of Utah. Journal of Vertebrate Paleontology, 18(2):403-411. https://doi.org/10.1080/ 02724634.1998.10011068

Cifelli, R.L., Madsen, S.K., and Larson, E.M. 1996. Screenwashing and associated techniques for the recovery of microvertebrate fossils. Oklahoma Geological Survey Special Publication, 96(4):1-24.

Cifelli, R.L., Wible, J.R., and Jenkins, F.A., Jr. 1998. Triconodont mammals from the Cloverly Formation (Lower Cretaceous), Montana and Wyoming. Journal of Vertebrate Paleontology, 18(2):237-241. https://doi.org/10.1080/02724634.1998.10011048

Clark, W.B. and Bibbins, A.B. 1897. Stratigraphy of the Potomac Group in Maryland. Journal of Geology, 5:479-506. https://doi.org/10.1086/607853

Cope, E.D. 1868. On some Cretaceous Reptilia. Proceedings of the Academy of Natural Sciences, 1868:233-300.

Cope, E.D. 1870. Synopsis of the extinct Batrachia, Reptilia and Aves of North America. Transactions of the American Philosophical Society, 14:1-252. https://doi.org/10.5962/ bhl.title.60499

Cope, E.D. 1875. Check-list of North American Batrachia and Reptilia; with a systematic list of the higher groups, and an essay on geographical distribution. Based on the specimens in the U.S. National Museum. Bulletin of the United States National Museum, 1:1-104. https:// doi.org/10.5962/bhl.title.11851

Cope, E.D. 1884. The Tertiary Marsupialia. American Naturalist, 18:686-697. https://doi.org/ $10.1086 / 273711$

Crompton, A.W. and Jenkins, F.A., Jr. 1968. Molar occlusion in Late Triassic mammals. Biological Reviews, 43:427-458. https://doi.org/10.1111/j.1469-185x.1968.tb00966.x

De Lapparent De Broin, F. and Murelaga, X. 1996. Une nouvelle faune de chéloniens dans le Crétacé supérieur européen. Comptes rendus de l'Académie des sciences. Série 2, Sciences de la terre et des planètes, 323(8):729-735.

D'Emic, M.D. 2012. Revision of the sauropod dinosaurs of the Lower Cretaceous Trinity Group, southern USA, with the description of a new genus. Journal of Systematic Palaeontology, 11:707-726. https://doi.org/10.1080/14772019.2012.667446

Dollo, L. 1883. Première note sur les crocodiliens de Bernissart. Bulletin du Musée Royal d'Histoire Naturelle de Belgique, 2:309-338.

Doyle, J.A. 2012. Molecular and fossil evidence on the origin of angiosperms. Annual Reviews of Earth and Planetary Sciences, 40:301-326. https://doi.org/10.1146/annurev-earth-042711105313

Doyle, J.A. and Robbins, E.T. 1977. Angiosperm pollen zonation of the continental Cretaceous of the Atlantic Coastal Plain and its application to deep wells in the Salisbury Embayment. Palynology, 1:43-78. https://doi.org/10.1080/01916122.1977.9989150

Eaton, J.G., Gardner, J.D., Kirkland, J.I., Brinkman, D.B., and Nydam, R.L. 2014. Vertebrates of the Iron Springs Formation, Upper Cretaceous, southwestern Utah. Utah Geological Association Guidebook, 43:523-555.

Egerton, P.M.G. 1845. Description of the mouth of a Hybodus found by Mr. Boscawen Ibbetson in the Isle of Wight. Quarterly Journal of the Geological Society, 1:197-199. https://doi.org/ 10.1144/gsl.jgs.1845.001.01.51 
Estes, R. and Sanchíz, B. 1982. Early Cretaceous lower vertebrates from Galve (Teruel), Spain. Journal of Vertebrate Paleontology, 2:21-39. https://doi.org/10.1080/ 02724634.1982 .10011915

Farlow, J.O., Brinkman, D.L., Abler, W.L., and Currie, P.J. 1991. Size, shape, and serration density of theropod dinosaur lateral teeth. Modern Geology, 16:161-198.

Fiorillo, A.R. 1999. Non-mammalian microvertebrate remains from the Robison Eggshell Site, Cedar Mountain Formation (Lower Cretaceous), Emery County, Utah, p. 259-268. In Gillette, D.D. (ed.), Vertebrate Paleontology in Utah, Special Publication 99(1). Utah Geological Survey, Salt Lake City.

Fischer, J. 2008. Brief synopsis of the hybodont form taxon Lissodus Brough, 1935, with remarks on the environment and associated fauna. Freiberger Forschungshefte $C, 528: 1-523$.

Fox, R.C. 1976. Additions to the mammalian local fauna from the upper Milk River Formation (Upper Cretaceous), Alberta. Canadian Journal of Earth Sciences, 13(8):1105-1118. https:// doi.org/10.1139/e76-113

Frederickson, J.A. and Cifelli, R.L. 2017. New Cretaceous lungfishes (Dipnoi, Ceratodontidae) from western North America. Journal of Paleontology, 91(1):146-161. https://doi.org/10.1017/ jpa.2016.131

Frederickson, J.A., Lipka, T.R., and Cifelli, R.L. 2016. A new species of the lungfish Ceratodus (Dipnoi) from the Early Cretaceous of the eastern USA. Journal of Vertebrate Paleontology, 36(4):e1136316. https://doi.org/10.1080/02724634.2016.1136316

Gauthier, J.A. 1986. Saurischian monophyly and the origin of birds. Memoirs of the California Academy of Sciences, 8:1-55.

Gill, T. 1872. Arrangement of the families of fishes, or classes Pisces, Marsipobranchii, and Leptocardii. Smithsonian Miscellaneous Collections, 11(247):1-49. https://doi.org/10.5962/ bhl.title.18974

Gilmore, C.W. 1921. The fauna of the Arundel Formation of Maryland. Proceedings of the United States National Museum, 59:581-594. https://doi.org/10.5479/si.00963801.59-2389.581

Glaser, J.D. 1967. Nonmarine Cretaceous Sedimentation in the Middle Atlantic Coastal Plain. Unpublished Ph.D. Dissertation, Johns Hopkins University, Baltimore, Maryland, USA.

Glaser, J.D. 1969. Petrology and origin of Potomac and Magothy (Cretaceous) sediments, middle Atlantic Coastal Plain. Maryland Geologic Survey, Report of Investigations, 10:1-101.

Goldberg, P. 2000. Faunal Composition, Non-marine Vertebrates, of the Upper Cedar Mountain Formation (Cretaceous: Albian-Cenomanian), Central Utah. Unpublished Ph.D. Dissertation, University of Oklahoma, Norman, Oklahoma, USA.

Grande, L. 2010. An empirical synthetic pattern study of gars (Lepisosteiformes) and closely related species, based mostly on skeletal anatomy. The Resurrection of Holostei. American Society of Ichthyologists and Herpetologists, Lawrence, Kansas.

Grande, L. and Bemis, W.E. 1998. A comprehensive phylogenetic study of amiid fishes (Amiidae) based on comparative skeletal anatomy. An empirical search for interconnected patterns of natural history. Memoir of the Society of Vertebrate Paleontology, 4:1-690. https:// doi.org/10.1080/02724634.1998.10011114

Groot, J.J. 1955. Sedimentary petrology of the Cretaceous sediments of northern Delaware in relation to paleogeographic problems. Delaware Geological Survey Bulletin, 5:1-157. https:// doi.org/10.1306/d4269869-2b26-11d7-8648000102c1865d

Hansen, H.J. 1969. Depositional environments of subsurface Potomac Group in southern Maryland. American Association of Petroleum Geologists Bulletin, 53(9):1923-1937. https:// doi.org/10.1306/5d25c88f-16c1-11d7-8645000102c1865d

Harmsen, G.W. 1954. Observations on the formation and oxidation of pyrite in the soil. Plant and Soil, 5(4):324-348. https://doi.org/10.1007/bf01354456

Harris, J.D. 1998. Large, Early Cretaceous theropods in North America. New Mexico Museum Natural History Science Bulletin, 14:225-228.

Hay, O.P. 1908. Fossil Turtles of North America. Carnegie Institute, Washington D.C. https:// doi.org/10.5962/bhl.title.12500

Hay, O.P. 1929. Second Bibliography and Catalogue of the Fossil Vertebrata of North America, Volume 1. Carnegie Institute, Washington D.C. https://doi.org/10.1086/623705

Hay, O.P. 1930. Second Bibliography and Catalogue of the Fossil Vertebrata of North America, Volume 2. Carnegie Institute, Washington D.C. https://doi.org/10.2307/1374076 
Heckert, A.B. 2004. Late Triassic microvertebrates from the lower Chinle Group (OtischalkianAdamanian: Carnian), southwestern U.S.A. New Mexico Museum of Natural History and Science Bulletin, 27:1-170.

Hochuli, P.A., Heimhofer, U., and Weissert, H. 2006. Timing of early angiosperm radiation: recalibrating the classical succession. Journal of the Geological Society, London, 163:587594. https://doi.org/10.1144/0016-764905-135

Huxley, T.H. 1880. On the application of the laws of evolution to the arrangement of the Vertebrata, and more particularly of the Mammalia. Proceedings of the Zoological Society of London, 43:649-662.

Johnston, C. 1859. Note upon odontology. American Journal of Dental Science New Series, 9:337-343.

Joyce, W.G., Sterli, J., and Chapman, S.D. 2014. The skeletal morphology of the solemydid turtle Naomichelys speciosa from the Early Cretaceous of Texas. Journal of Paleontology, 88(6):1257-1287. https://doi.org/10.1666/14-002

Jud, N.A. and Hickey, L.J. 2013. Potamocapnos apeleutherodon gen. et sp. nov., a new Early Cretaceous angiosperm from the Potomac Group and its implications for the evolution of eudicot leaf architecture. American Journal of Botany, 100:2437-2449. https://doi.org/ 10.3732/ajb. 1300250

Jud, N.A. 2015. Fossil evidence for a herbaceous diversification of early eudicot angiosperms during the Early Cretaceous. Proceedings of the Royal Society, Series B, 282(1814). https:// doi.org/10.1098/rspb.2015.1045

Kemp, A. 1996. Sagenodus (Proceratodus) carlinvillensis (Romer and Smith 1934), (Osteichthyes: Dipnoi), short ridge anomaly and classification of dipnoans. Journal of Vertebrate Paleontology, 16:16-19. https://doi.org/10.1080/02724634.1996.10011279

Kemp, A. 1997. A revision of Australian Mesozoic and Cenozoic lungfish of the family Neoceratodontidae (Osteichthyes: Dipnoi), with a description of four new species. Journal of Paleontology, 71:713-733. https://doi.org/10.1017/s0022336000040166

Kermack, K.A., Mussett, F., and Rigney, H.W. 1973. The lower jaw of Morganucodon. Journal of the Linnean Society (Zoology), 53:87-175. https://doi.org/10.1111/j.10963642.1973.tb00786.x

Kielan-Jaworowska, Z. and Hurum, J.H. 2001. Phylogeny and systematics of multituberculate mammals. Palaeontology, 44:389-429. https://doi.org/10.1111/1475-4983.00185

Kirkland, J.I. 1987. Upper Jurassic and Cretaceous lungfish tooth plates from the Western Interior, the last dipnoan faunas of North America. Hunteria, 2(2):1-16.

Kirkland, J.I. 1998. Morrison fishes. Modern Geology, 22:503-533.

Kirkland, J.I., Cifelli, R.L., Britt, B.B., Burge, D.L., DeCourten, F.L., Eaton, J.G., and Parrish, J.M. 1999. Distribution of vertebrate faunas in the Cedar Mountain Formation, east-central Utah, p. 201-217. Vertebrate Paleontology in Utah: Utah Geological Survey Miscellaneous Publication.

Klein, E.F. 1885, Beiträge zur Bildung des Schädels der Knochenfische, 2. Jahreshefte des Vereins für Vaterländische Naturkunde in Württemberg, 42:205-300.

Klein, I.T. 1751. Quadrupedum Dispositio Brevisque Historia Naturalis. Ionam Schmidt, Leipzig.

Knight, W.C. 1898. Some new Jurassic vertebrates from Wyoming. American Journal of Science, 5:186. https://doi.org/10.2475/ajs.s4-5.27.186

Kraft, J.C., Sheridan, R.E., and Maisano, M. 1971. Time-stratigraphic units and petroleum entrapment models in Baltimore Canyon basin of Atlantic continental margin geosynclines. AAPG Bulletin, 55(5):658-679. https://doi.org/10.1306/819a3c52-16c5-11d78645000102c1865d

Kranz, P.M. 1989. Dinosaurs in Maryland. Maryland Geological Survey, Educational Series No. 6, Baltimore, Maryland.

Kranz, P.M. 1996. Notes on the sedimentary iron ores of Maryland and their dinosaurian fauna. Maryland Geological Survey, Special Publication, 3:87-115.

Kranz, P.M. 1998a. Mostly dinosaurs: a review of the vertebrates of the Potomac Group (Aptian Arundel Formation), USA, p. 235-238. In Lucas, S.G., Kirkland, J.I., and Estep, J.W. (eds.), Lower and Middle Cretaceous Terrestrial Ecosystems. New Mexico Museum of Natural History and Science Bulletin 14, Albuquerque.

Kranz, P.M. 1998b. New fossil turtles from the Potomac Group, p. 193-194. In Lucas, S.G., Kirkland, J.I., and Estep, J.W. (eds.), Lower and Middle Cretaceous Terrestrial Ecosystems. New Mexico Museum of Natural History and Science Bulletin 14, Albuquerque. 
Langston, W., Jr. 1974, Nonmammalian Comanchean tetrapods: Geoscience and Man, 8:77102.

Larson, D.W. and Currie, P.J. 2013. Multivariate analyses of small theropod dinosaur teeth and implications for paleoecological turnover through time. PLOS ONE, 8:e54329. https://doi.org/ 10.1371/journal.pone.0054329

Leidy, J. 1865. Memoir on the extinct reptiles of the Cretaceous formations of the United States. Smithsonian Contributions to Knowledge, 14(6):1-135.

Linnaeus, C. 1758. Systema Naturae per Regna Tria Naturae, secundum Classes, Ordines, Genera, Species, cum Characteribus, Differentiis, Synonymis, Locis, Tomus 1. Laurentii Salvii, Stockholm.

Lipka, T.R. 1998. The affinities of the enigmatic theropods of the Arundel Clay facies (Aptian), Potomac Formation, Atlantic coastal plain of Maryland, p. 229-234. In Lucas, S.G., Kirkland, J.I., and Estep, J.W. (eds.), Lower and Middle Cretaceous Terrestrial Ecosystems. New Mexico Museum of Natural History and Science Bulletin 14, Albuquerque.

Lipka, T.R., Therrien, F., Weishampel, D.B., Jamniczky, H.A., Joyce, W.G., Colbert, M.W., and Brinkman, D.B. 2006. A new turtle from the Arundel Clay facies (Potomac Formation, Early Cretaceous) of Maryland, U.S.A. Journal of Vertebrate Paleontology, 26:300-307. https:// doi.org/10.1671/0272-4634(2006)26[300:antfta]2.0.co;2

Lull, R.S. 1911. Systematic paleontology of the Lower Cretaceous deposits of Maryland. Maryland Geological Survey, Lower Cretaceous, 183-211.

Makovicky, P.J., Kobayashi, Y., and Currie, P.J. 2004. Ornithomimosauria, p. 137-115. In Weishampel, D.B., Dodson, P., and Osmolska, H. (eds.), The Dinosauria. University of California Press, Berkeley.

Maisey, J.G. 1983. Cranial anatomy of Hybodus basanus Egerton from the Lower Cretaceous of England. American Museum Novitates, 2758:1-64.

Maisey, J.G. 1987. Cranial anatomy of the Lower Jurassic shark Hybodus reticulatus (Chondrichthyes: Elasmobranchii), with comments on hybodontid systematics. American Museum Novitates, 2878:1-19.

Marsh, O.C. 1881. Principal characters of American Jurassic dinosaurs, part V. American Journal of Science, 21:417-423. https://doi.org/10.2475/ajs.s3-21.125.417

Marsh, O.C. 1887. American Jurassic mammals. American Journal of Science, 33:326-348. https://doi.org/10.2475/ajs.s3-33.196.327

Marsh, O.C. 1888. Notice of a new genus of Sauropoda and other new dinosaurs from the Potomac Formation. American Journal of Science, 35(3):89-94. https://doi.org/10.2475/ ajs.s3-35.205.89

Marsh, O.C. 1890. Notice of some extinct Testudinata. American Journal of Science, 40(3):177179. https://doi.org/10.2475/ajs.s3-40.236.177

Matthew, W.D. and Brown, B. 1922. The family Deinodontidae, with notice of a new genus from the Cretaceous of Alberta. Bulletin of the American Museum of Natural History, 46:367-385.

Müller, J. 1846. Über den Bau und die Grenzen der Ganoiden und über das System natürliche der Fische. Abhandlungen der Königlichen Akademie der Wissenschaften zu Berlin, 1844:117-216.

Neuman, A.G. and Brinkman, D.B. 2005. Fishes of the fluvial beds, p. 167-185. In Currie, P.J. and Koppelhus, E.B. (eds.), Dinosaur Provincial Park: A Spectacular Ancient Ecosystem Revealed. Indiana University Press, Bloomington.

Oreska, M.P., Carrano, M.T., and Dzikiewicz, K.M. 2013. Vertebrate paleontology of the Cloverly Formation (Lower Cretaceous), I: faunal composition, biogeographic relationships, and sampling. Journal of Vertebrate Paleontology, 33(2):264-292. https://doi.org/10.1080/ 02724634.2012.717567

Osborn, H.F. 1923. Two Lower Cretaceous dinosaurs of Mongolia. American Museum Novitates, 95:1-10.

Ostrom, J.H. 1969a. A new theropod dinosaur from the Lower Cretaceous of Montana. Postilla, 128:1-17.

Ostrom, J.H. 1969b. Osteology of Deinonychus antirrhopus, an unusual theropod from the Lower Cretaceous of Montana. Peabody Museum of Natural History Bulletin, 30:1-165.

Ostrom, J.H. 1970. Stratigraphy and paleontology of the Cloverly Formation (Lower Cretaceous) of the Bighorn Basin area, Wyoming and Montana. Peabody Museum of Natural History Bulletin, 35:1-234. 
Owen, R. 1842. Report on British fossil reptiles, part 2. Report of the British Association for the Advancement of Science, 11:60-204.

Patterson, B. 1951. Early Cretaceous mammals from northern Texas. American Journal of Science, 249:31-46. https://doi.org/10.2475/ajs.249.1.31

Patterson, C. 1966. British Wealden sharks. Bulletin of the British Museum (Natural History), Geology, 11:281-350.

Reinhardt, J., Christopher, R., and Owens, J. 1980. Lower Cretaceous stratigraphy of the core, p. 31-52. In Geology of the Oak Grove Core. Virginia Division of Mineral Resources Publication, Charlottesville, Virginia.

Rios-López, N. 2008. Effects of increased salinity on tadpoles of two anurans from a Caribbean coastal wetland in relation to their natural abundance. Amphibia-Reptilia, 29:7-18. https:// doi.org/10.1163/156853808783431451

Romer, A.S. 1955. Herpetichthyes, Amphibioidei, Choanichthyes or Sarcopterygii? Nature, 176:126. https://doi.org/10.1038/176126a0

Rose, K.D., Cifelli, R.L., and Lipka, T.R. 2001. Second triconodont dentary from the Early Cretaceous of Maryland. Journal of Vertebrate Paleontology, 21:628-632. https://doi.org/ 10.1671/0272-4634(2001)021[0628:stdfte]2.0.co;2

Schultze, H.P. 1981. A dipnoan tooth plate from the Lower Cretaceous of Kansas, USA. Transactions of the Kansas Academy of Science, 1903:187-195. https://doi.org/ $10.2307 / 3628273$

Seeley, H.G. 1887. On the classification of the fossil animals commonly named Dinosauria. Proceedings of the Royal Society of London, 43:165-171. https://doi.org/10.1098/ rspl.1887.0117

Sereno, P.C. 1986. Phylogeny of the bird-hipped dinosaurs (Order Ornithischia). National Geographic Research, 2(2):234-256.

Smith, D. and Galton, P. 1990. Osteology of Archaeornithomimus asiaticus (Upper Cretaceous, Iren Dabasu Formation, People's Republic of China). Journal of Vertebrate Paleontology, 10(2):255-265. https://doi.org/10.1080/02724634.1990.10011811

Stanford, R., Weishampel, D.B., and Deleon, V.B. 2011. The first hatchling dinosaur reported from the eastern United States: Propanoplosaurus marylandicus (Dinosauria: Ankylosauria) from the Early Cretaceous of Maryland, USA. Journal of Paleontology, 85(5):916-924. https:/ /doi.org/10.1666/10-113.1

Stovall, J.W. and Langston, W. 1950. Acrocanthosaurus atokensis, a new genus and species of Lower Cretaceous Theropoda from Oklahoma. American Midland Naturalist, 43(3):696-728. https://doi.org/10.2307/2421859

Stromer, E. 1931. Ergebnisse der Forschungsrisen Prof. E. Stromers in den Wüsten Ägyptens. II. Wirbeltierreste der Baharje-Stufe (unterstes Cenoman). 10. Ein Skelett-Rest von Carcharodontosaurus no. gen. Abhandlungen der Bayerischen Akademie der Wissenschaften Mathematisch-Naturwissenschaftliche Abteilung, 9:1-23.

Suarez, C., González, L., Ludvigson, G., Cifelli, R.L., and Tremain, E. 2012. Water utilization of the Cretaceous Mussentuchit Member local vertebrate fauna, Cedar Mountain Formation, Utah: using oxygen isotopic composition of phosphate. Palaeogeography, Palaeoclimatology, Palaeoecology, 313-314:78-92. https://doi.org/10.1016/ j.palaeo.2011.10.011

Thurmond, J.T. 1971. Cartilaginous fishes of the Trinity Group and related rocks (Lower Cretaceous) of north central Texas. Southeastern Geology, 13:207-227.

Turnbull, W.D. and Cifelli, R.L. 1999. Triconodont mammals of the Aptian-Albian Trinity Group, Texas and Oklahoma, p. 252-272. In Mayhall, J.T. and Heikkinen T. (eds.), Dental Morphology. University of Oulu Press, Oulu.

Underwood, C.J. and Cumbaa, S.L., 2010. Chondrichthyans from a Cenomanian (Late Cretaceous) bonebed, Saskatchewan, Canada. Palaeontology, 53(4):903-944. https:// doi.org/10.1111/j.1475-4983.2010.00969.x

Underwood, C.J. and Rees, J. 2002. Selachian faunas from the lowermost Cretaceous Purbeck Group of Dorset, southern England. Life and Environments in Purbeck Times (Special Papers in Palaeontology), 68:83-101.

von Huene, E. 1932. Die fossile Reptil-Ordnung Saurischia, ihre Entwicklung und Geschichte. Monographien zur Geologie und Palaeontologie ser, 1(4):1-361.

von Zittel, K.A. and Eastman, C.R. 1902. Text-Book of Palaeontology, Volume 2. Macmillan and Co., London. 
Weems, R.E. and Bachman, J.M. 1997. Cretaceous anuran and dinosaur footprints from the Patuxent Formation of Virginia. Proceedings of the Biological Society of Washington, 110:117.

Weems, R.E. and Bachman, J.M. 2015. The Lower Cretaceous Patuxent Formation ichnofauna of Virginia. Ichnos, 22:208-219. https://doi.org/10.1080/10420940.2015.1063493

Weishampel, D.B. and Young, L. 1996. Dinosaurs of the East Coast. Johns Hopkins University Press, Baltimore, Maryland.

Winkler, D.A., Murry, P.A., and Jacobs, L.L. 1990. Early Cretaceous (Comanchean) vertebrates of central Texas. Journal of Vertebrate Paleontology, 10(1):95-116. https://doi.org/10.1080/ 02724634.1990 .10011794

Woodward, A.S. 1890. The fossil fishes of the Hawkesbury Series at Gosford, New South Wales. Memoirs of the Geological Survey of New South Wales, Palaeontology, 4:1-57. https:// doi.org/10.1080/00222939008694061

Woodward, A.S. 1916. The fossil fishes of the English Wealden and Purbeck formations. Part I. Monograph of the Palaeontographical Society of London, 69:1-48. https://doi.org/10.1017/ cbo9781139680851

Woodward, A.S. and Sherborn, C.D. 1890. A Catalogue of British Fossil Vertebrata. Dulau and Co., London. https://doi.org/10.5962/bhl.title.62185 